\title{
A Classical View of the Business Cycle
}

\author{
Michael T. Belongia \\ Otho Smith Professor of Economics \\ University of Mississippi \\ Box 1848 \\ University, MS 38677 \\ mvpt@earthlink.net
}

\author{
Peter N. Ireland \\ Department of Economics \\ Boston College \\ 140 Commonwealth Avenue \\ Chestnut Hill, MA 02467 \\ peter.ireland@bc.edu
}

November 2016

\begin{abstract}
In the 1920s, Irving Fisher extended his previous work on the Quantity Theory to describe how, through an early version of the Phillips Curve, changes in the price level could affect both output and unemployment. At the same time, Holbrook Working designed a quantitative rule for achieving price stability through control of the money supply. This paper develops a structural vector autoregressive time series model that allows these "classical" channels of monetary transmission to operate alongside, or perhaps even instead of, the nowmore-familiar interest rate channels of the canonical New Keynesian model. Even with Bayesian priors that intentionally favor the New Keynesian view, the United States data produce posterior distributions for the model's key parameters that are more consistent with the ideas of Fisher and Working. Changes in real money balances enter importantly into the model's aggregate demand relationship, while growth in Divisia M2 appears in the estimated monetary policy rule. Contractionary monetary policy shocks reveal themselves through persistent declines in nominal money growth instead of rising nominal interest rates. These results point to the need for new theoretical models that capture a wider range of channels through which monetary policy affects the economy and suggest that, even today, the monetary aggregates could play a useful role in the Federal Reserve's policymaking strategy.
\end{abstract}

JEL Codes: B12, E31, E32, E41, E43, E52.

Keywords: Bayesian vector autoregression, Divisia monetary aggregate, Monetary transmission mechanism, New Keynesian model, Quantity Theory of money.

Acknowledgments: We are especially grateful to David Laidler for his encouragement during the development of this paper; all errors that remain are our own. Neither of us received any external support for, or has any financial interest that relates to, the research described in this paper. 


\section{Introduction}

The New Keynesian model used for much of modern business cycle analysis consists, at its core, of three equations: forward-looking Phillips and IS Curves, together with an interest rate rule for monetary policy. Central element of this model include some form of administrative cost or information rigidity that prevents firms from adjusting their output prices fully and immediately in response to shocks that hit the economy. As well, households exhibit a willingness to rearrange their spending patterns in response to changes in the real interest rate as an intertemporal price. In this model, the effects of monetary policy actions on output and prices are transmitted exclusively through the central bank's manipulation of the short-term nominal interest rate. Temporary rigidity in goods prices also allows these nominal interest rate movements to affect real interest rates. These changes in turn then generate adjustments in household spending that affect the output gap and feed back into firms' pricing decisions via the Phillips Curve. Notably missing from the model is any separate role for variations in the quantity of money. ${ }^{1}$

Approximately ninety years ago, Irving Fisher $(1923,1925,1926)$ and Holbrook Working (1923, 1926) developed an alternative view of the monetary transmission mechanism that is associated here with a "classical" school of thought. Quite unlike much more recent real business cycle models, this older classical view does not deny the importance of nominal price rigidities and the resulting monetary non-neutralities in shaping business cycle dynamics. For example, as explained in more detail below, Fisher (1926) discovered a statistical relationship between inflation and employment that resembles closely what would later become known as the Phillips Curve. ${ }^{2}$ And Fisher's $(1923,1925)$ description of the "so-called business cycle" as a

\footnotetext{
${ }^{1}$ More precisely, changes in the real and nominal quantities of money play no independent role in determining the dynamics of inflation, the output gap, and the short-term nominal interest rate in the standard New Keynesian model. However, one can still view the central bank's choice for the average rate of nominal money supply growth as important for the determination of the model's steady-state rate of inflation. See Ireland (2004) and Nelson (2008) for more detailed discussions of this distinction.

${ }^{2}$ In fact, Fisher (1926) was republished as Fisher (1973) under the alternative title "I Discovered the Phillips Curve."
} 
product of the "dance of the dollar" singles out nominal impulses as the primary driver of aggregate fluctuations.

Missing from Fisher's analyses was a full explanation of how this nominal instability could be traced back to the effects of monetary policy itself. Based on Fisher's earlier research, however, Laidler (2013) argues that Fisher must have seen variations in the quantity of money as the more fundamental source of what today would be labeled as "monetary policy shock." Along those lines, Fisher (1925) refers to Holbrook Working's then-forthcoming 1926 paper, which found that movements in bank deposits tended to lead movements in the aggregate price level. In related research, Working (1923) uses a Quantity Theory framework complementary to Fisher's to characterize a path for the money stock that would be consistent with long-run price stability and, by extension, enhanced real stability as well.

After reviewing in greater detail the original work behind this classical view of the monetary business cycle, this paper proceeds to sharpen both its points of similarity to and its departures from the more contemporary, New Keynesian perspective. The paper then conducts an empirical exercise aimed at discovering whether the classical channels of monetary transmission, working through Quantity-Theoretic interactions between the supply of and demand for money, might operate alongside, or perhaps even instead of, the now much more familiar New Keynesian interest rate channels.

Adapting methods outlined by Baumeister and Hamilton (2015a, 2015b), the econometric study begins by estimating a structural vector autoregression (VAR) for inflation, the output gap, and the federal funds rate under Bayesian priors that reflect the mainstream, New Keynesian view of the cycle. Next, the VAR is expanded to include a Divisia monetary aggregate and the associated Divisia user cost index, using both of these new variables to help distinguish fluctuations in money supply from those in money demand. Although the Bayesian priors chosen for this expanded model continue to deliberately reflect the New Keynesian view that any additional, classical channels of monetary transmission are of limited importance, quarterly data for the United States turn out to speak strongly in favor of their existence. Posterior distributions tilt heavily towards specifications that allow terms involving real and 
nominal money growth to enter into IS and monetary policy equations that, according to the strict New Keynesian view, ought to involve real and nominal interest rates alone. Reflecting the importance of these additional terms, contractionary monetary policy shocks appear, in this more general framework, to be triggered mainly by persistent reductions in nominal money growth that are followed by declines in inflation, the output gap, and the short-term nominal interest rate. And while the fall in the nominal interest rate is easy to explain based on the coincident decline in inflation, this movement appears strikingly different from what is implied by a purely New Keynesian model that associates tighter monetary policy with rising nominal interest rates. The paper's conclusion discusses the implications of these findings for business cycle theory because, at a minimum, they seem to call for a new class of models capable of capturing a wider range of channels through which monetary policy affects the economy. The results also suggest that, even today, monetary aggregates could play a useful role in the Federal Reserve's policymaking strategy.

\section{A Classical View of the Monetary Business Cycle}

Long before the development of real business cycle and New Keynesian theories, Irving Fisher $(1923,1925)$ published his own ideas on what forces might be behind aggregate fluctuations. In these papers, Fisher presented evidence that different speeds of adjustment between the prices received by producers for their output and prices paid by firms for their inputs led to variations in profits because input prices were more sticky. Thus, in Fisher's view, unanticipated variations in the inflation rate became a key driving force of "the cycle."3 Changes in inflation also would affect real interest rates, potentially lowering the cost of borrowing by firms. As bank loans were affected by these changes in output and interest rates, the growth of bank deposits and, hence, the quantity of money, would be altered as well. And with this change in money growth, a feedback loop was created wherein the resulting change in money growth would again affect inflation, propagating further the effects of the initial impulse.

3 These papers as well as Fisher (1926), which related inflation and unemployment, are discussed at length by Laidler (2013). 
An important element of Fisher's description of the business cycle was his emphasis that output was affected by the rate of change of the price level rather than the price level itself. He illustrated this relationship by showing plots of these series and reporting, with the help of an early notion of distributed lags, correlation coefficients associating the inflation rate and output across various intervals of time; he found the strongest correlation to be at nine months. On the basis of this analysis, Fisher concluded that there was no inherent business cycle and that, instead, any observed fluctuations in output were due to variations in inflation. In Fisher's own words, the "so-called business cycle" was nothing more than a consequence of the "dance of the dollar." Missing from this analysis was any explicit treatment of a causal force that led to variations in the first place. Based on his earlier research, however, it seems clear that Fisher had variations in the quantity of money as that force. For example, Fisher treated the subject extensively in his (1911) Purchasing Power of Money and, for several years, he published forecasts of inflation in the American Economic Review. These forecasts were derived from Quantity Theory relationships and based on regressions of the aggregate price level on the quantity of money. ${ }^{5}$

Only a few years later, Fisher (1926) outlined a relationship between the price level and employment in the same spirit of what would later become known as the Phillips Curve. Moreover, this exercise was, in many ways, simply another effort by Fisher to demonstrate that the phenomenon described as the business cycle was no more and no less than a consequence of fluctuations in inflation. In it, Fisher again emphasized that it is inflation and not the price level that drives changes in real activity. And while his earlier papers explored the correlations between inflation and the volume of trade, this work analyzed the association between inflation

${ }^{4}$ Laidler (2013) argues that this research can be seen as an effort by Fisher to confirm his long-standing belief in the power of the Quantity Theory to explain aggregate fluctuations and to support his advocacy of a rule that would direct the newly-created Federal Reserve to achieve price stability. This was his "compensated dollar plan;" see Fisher $(1913,1920)$. Simons (1936) later articulated similar logic for the adoption of a monetary policy rule.

${ }^{5}$ See, as only one example, Fisher (1912). Also, as noted above, Fisher (1925) supported his general argument by citing research by Holbrook Working, who had found that bank deposits tended to lead the price level; these findings were published soon thereafter in Working (1926). 
and employment. ${ }^{6}$ As before, Fisher used distributed lags to calculate correlations at different frequencies because

... it stands to reason that correlating with a fixed lag is an extremely inadequate method; for if, at any one time, inflation is going on rapidly ... the effect on employment will not certainly wait for seven months and then suddenly explode, or be felt all at once, and after that not be felt at all. Instead, its effect will be distributed. It is on this consideration of the actual facts that I have introduced the idea of a distributed lag .... Having tried various types of frequency or probability curves, I have found that one approximating to a simplified "geometrical" probability curve ... seems best suited to show the effect of P' [changes in the price level] on unemployment or employment. (Fisher 1926, pp.789-790)

Fisher now had found more evidence that variations in real activity were related to inflation but, in this paper, did not explain why prices varied. Nonetheless, based on his earlier (1911) investigations of the Quantity Theory and, specifically, that book's Chapter IV ("Disturbance of Equation [of Exchange] and of Purchasing Power during Transition Periods"), which connected variations in money to variations in the price level and, subsequently, to changes in the real rate of interest and output, it is reasonable to infer that he saw variations in the quantity of money as the underlying source of aggregate fluctuations. ${ }^{7}$

If variations in the price level were, in fact, the cause of fluctuations in aggregate activity, it would be natural to ask if there were a mechanism by which price stability might be achieved and, indeed, Fisher $(1913,1920)$ had already proposed that price stability be adopted formally as the operating objective of the Federal Reserve. In this context, Working's contribution was to use the Quantity Theory to define a mechanism by which a value for the money supply consistent with long-run price stability could be identified. Moreover, Working recognized the role of lags between changes in the quantity of money and changes in the price level and embedded these lags in a policy framework based on a long-run simulated path for

6 Throughout the paper, Fisher refers to both employment and unemployment. His statistical evidence, however, is limited only to variations in employment. In a subsequent paper, Fisher (1936) revisited the question by investigating the relationship between the rate of change in wholesale prices and factory employment. The theoretical reasoning for this exercise remained the same as that articulated in Fisher $(1925,1926)$.

${ }^{7}$ Fisher was not alone in making empirical investigations of Quantity Theory relationships in the early 20th century. For more background, see the surveys in Humphrey (1973) and Laidler (2013). 
price stability. By comparing the current price level against the simulated long-run path a central bank could then evaluate whether the stance of monetary policy was too accommodative or too restrictive. 8

The foregoing discussion suggests that business cycle dynamics as viewed from a classical perspective reflect the operation of the same three relationships found in the New Keynesian model: a relationship between the output gap (or unemployment) and inflation, a relationship between monetary policy and the output gap, and a rule for the conduct of monetary policy. But, while similar in concept, the specifics of these relationships differ in important ways across the two perspectives. These differences are highlighted below.

\section{Comparisons to and Contrasts with the New Keynesian Model}

\section{The Process of Price Adjustment and the Phillips Curve}

The modern New Keynesian model most frequently adopts a mechanism for staggered price setting that is taken from Calvo (1983). In it, two types of firms are identified: those that can change prices in the current period and those that cannot. Whether a specific firm is allowed to change its prices is determined by random chance and, when that firm does set a new price, it must recognize that the duration of the interval until that price can be changed also is unknown. Price setting, therefore, becomes a forward-looking exercise. The optimal price itself is determined by a mark-up over marginal cost, which empirical studies often proxy with a measure of the output gap.

This New Keynesian Phillips Curve differs from more traditional specifications not only in the role it assigns to expectations of future inflation, but also because of the simultaneity between inflation and the output gap that it allows. King and Watson (1994) emphasize this second point of contrast: traditional Keynesian identification schemes viewed the output gap or unemployment rate as predetermined relative to inflation so that, in a regression equation,

\footnotetext{
${ }^{8}$ Humphrey (2001) conjectures that a Quantity Theoretic rule of this type would have indicated to the Fed that monetary policy was excessively tight in the late 1920s and early 1930s in contrast to the signal of monetary ease given by the Real Bills Doctrine that guided the Fed at that time.
} 
inflation could be treated as the dependent variable and the output gap as the independent variable. As suggested above, Fisher's classical view appears to reverse the left and right-hand side variables, treating inflation as the variable that "causes" movements in the output gap. Laidler $(1978,1990)$ discusses at length this contrast between traditional Fisherian and Keynesian formulations of the Phillips Curve equation, reaching a conclusion similar to Lucas' (1996, p.679): that "though the evidence seems to show that monetary surprises have real effects, they do not seem to be transmitted through price surprises" as the strict Fisherian view would predict. 9

The analysis here, therefore, adapts Fisher's view of the Phillips Curve to fit the evidence. It accepts, in particular, the New Keynesian proposition that there is likely to be a simultaneous relationship between inflation and the output gap, summarized in the economy's aggregate supply relationship. This choice sets the classical model that is estimated below apart, not just from real business cycle theories, but also from the earlier theoretical and empirical models of Lucas (1972, 1973), Sargent and Wallace (1975), and Sargent (1976), which attempt to link statistical innovations in prices to movements in output and unemployment in a manner more consistent with Fisher's original analysis.

\section{The IS Curve and the Determination of Output}

The New Keynesian model includes a forward-looking IS curve expressed as a loglinearized version of an optimizing household's Euler equation that links expected consumption growth to the ex-ante real interest rate. As such, the New Keynesian IS curve merely extends Fisher's (1930) theory of the real interest rate and intertemporal choice to the case of uncertainty. The New Keynesian model, however, translates this Euler equation into the foundations of a theory of short-run output determination by assuming, additionally, that monopolistically competitive firms sell output on demand at their pre-set nominal prices and that the central bank exploits the temporary rigidity of nominal goods prices to translate policy-induced movements in nominal interest rates into corresponding movements in the real

9 Laidler (1978, 1990) discusses, as well, Milton Friedman's ambivalent views of the Phillips Curve, which often appeared to alternate between classical and Keynesian perspectives. 
interest rate. After imposing equilibrium conditions that link household spending to the output gap, the New Keynesian IS curve relates the output gap to the difference between the actual real interest rate and a corresponding measure of the natural real rate of interest. 10

The body of classical thought discussed earlier pre-dates any notion of an IS curve that might be compared directly to the New Keynesian specification. Nonetheless, a contrast can be made by recalling that, for Fisher and Working, it was changes it money growth that set off the dynamics through which monetary policy affected output and inflation. This observation suggests a classical alternative to the New Keynesian IS curve in which real money balances appear, either in addition to or instead of, the real interest rate as a summary statistic representing the channels through which monetary policy affects real economic activity. Ireland (2004) derives an IS curve of this form by assuming real money balances enter nonseparably with consumption into a representative household's utility function, so that the intertemporal optimality condition that forms the basis for the New Keynesian aggregate demand relation includes real balances as well as the real interest rate. Likewise, Nelson (2002) introduces adjustment costs of money demand into a New Keynesian model to derive a specification in which changes in real money balances reflect movements in long-term interest rates that are important in influencing aggregate demand; this model variant also motivates an empirical specification in which aggregate demand depends on changes in real money balances as well as the real short-term rate. In a similar spirit, Meltzer (2001) incorporates real money growth as well as interest rates into an empirical aggregate demand formulation, interpreting changes in real balances as proxies for the wider range of effects that monetary policy actions have on spending patterns. The classical model specified below takes the same approach, using the New Keynesian IS curve as its benchmark but allowing changes in real balances to enter that relationship as well so as to see, more broadly, which variables appear most important in transmitting the effects of monetary policy to output.

10 See Woodford (2003, Ch.4) for a derivation of this "Neo-Wickselian" view of aggregate demand and Neiss and Nelson (2003) for further theoretical and empirical analysis. 


\section{The Monetary Policy Rule}

The New Keynesian model is closed by a third equation that represents a monetary policy rule for the central bank. With changes in a short-term interest rate thought to be the primary determinant of output, the rule adopted for this purpose is focused on how the target value for that interest rate should be adjusted in response to prevailing economic conditions. Moreover, because the Federal Reserve's mandate specifies goals for two variables - stable prices and maximum employment - and because the output gap appears more frequently as the measure of resource utilization in the New Keynesian model, this rule naturally takes the same general form as Taylor's (1993), prescribing a setting for the nominal interest rate with reference to movements in inflation away from the central bank's target and fluctuations in the output gap.

In a classical setting, however, the quantity of money is the focus of a rule for monetary policy and, in contrast to the joint objectives of full employment and price stability for the central bank in New Keynesian models, classical rules directed their attention only to price stability. This sharper focus is, in part, due to the Quantity Theory relationships that serve as its foundation but, as well, to the maintained hypothesis that there would be no "cycle" if price stability were maintained. Thus, to derive a practical monetary policy rule, Working (1923) rewrote the basic expression of the Quantity Theory as $(\mathrm{V} / \mathrm{T})=(\mathrm{P} / \mathrm{M})$; then, because $\mathrm{P} / \mathrm{M}$ did not have a "definite conception," Working dealt with its reciprocal. To find a long-run path for it, Working estimated a trend value using a regression of the logarithm of the price level on time, time squared, and time cubed; he then identified targets for future values of the price level by extrapolating from this trend regression. With this information, Working then could plot, on a $\log$ scale, values for $\mathrm{M} / \mathrm{P}$ to illustrate the value of the money stock $\mathrm{M}$ that would be consistent with the long-run trend path for the aggregate price level P. ${ }^{11}$ And, in the same sense that the Taylor Rule directs the central bank to raise or lower its target for the short-term nominal

11 The "P-star" model of Hallman, Porter, and Small (1991) was adapted from Working's (1923) framework. But whereas that study specified velocity as a constant, Orphanides and Porter (2000) and Belongia and Ireland (2015a, 2016a) introduced time-varying measures of velocity, a change that tightened links between money and nominal objectives. 
interest rate as realized values for inflation and the output gap differ from their targets, the rule proposed by Working would have the central bank increase or decrease the quantity of money as the price level differed from its desired path.

In contrast to the Taylor (1993) Rule, however, which was originally proposed as a way describe how the Federal Reserve did behave over the period from 1987 through 1992, the feedback rule proposed by Working (1923) can be interpreted as proscriptive, the outline of a strategy the Fed would follow if it used its influence over the money supply to stabilize inflation around a target path. As such, the focus here shifts to the role that money growth plays in describing the implications that Federal Reserve policy decisions have actually had over various historical periods extending from the late 1960s through the present. Accordingly, meant as a positive description of Fed behavior and its consequences over these periods, the monetary policy rule in the classical variant of the model estimated below allows for contemporaneous links between the short-term nominal interest rate, the rate of nominal money growth, the output gap, and inflation. In the special case where no separate role for money growth appears, this rule collapses to the standard Taylor Rule. More generally, however, the specification allows monetary policy shocks to manifest themselves in movements in interest rates, money growth, or some combination of the two. The model's expanded IS curve then allows movements in both interest rates and money growth to affect aggregate demand and, from there, inflation as well through the Phillips Curve. Money Demand and Supply

Leeper and Roush (2003) emphasize that a standard Taylor Rule describes part of a broader monetary regime in which Federal Reserve policy makes the supply of monetary assets infinitely elastic with respect to changes in the short-term nominal interest rate. It is this infinite elasticity of money supply that implies that a money demand equation, if added to the New Keynesian model, serves only to determine the equilibrium stock of money, given the behavior of inflation, output, and interest rates. By contrast, a policy rule allowing for simultaneity between interest rates and money growth makes money supply less than fully elastic, and therefore requires an explicit consideration of money demand to pin down the 
dynamics of all other variables. Thus, the classical model developed below goes beyond the three-variable New Keynesian specification, not only by making the IS and monetary policy rules more flexible, but also by including entirely new relationships that clarify the distinction between money supply and money demand. The resulting description of monetary policy and its effects, working through the interaction between money supply and demand, highlights much deeper connections between the analysis conducted here and the classical ideas of Fisher and Working and, likewise, reveals a more fundamental departure from the standard New Keynesian approach.

\section{The New Keynesian Benchmark}

To demonstrate, first, that the empirical approach taken here is capable of producing results consistent with conventional, New Keynesian theory as a benchmark, the analysis begins by focusing on a three-variable structural vector autoregression for inflation $p_{t}$, the output gap $y_{t}$, and the short-term nominal interest rate $r_{t}$. The quarterly data used to estimate this VAR begin in 1967:1, to match the availability of the monetary series used to extend the model later on, and run through 2016:2. In those data, inflation is measured by year-over-year percentage changes in the price index for personal consumption expenditures, and the output gap is measured as the percentage-point difference between real GDP and the Congressional Budget Office's estimate of potential GDP. From the beginning of the sample period through 2008:4 and starting again in 2016:1, the short-term nominal interest rate is measured by the effective federal funds rate. From 2009:1 through 2015:4, it is measured instead using Wu and Xia's (2016) shadow federal funds rate, which provides a convenient onedimensional index summarizing the full effects of the Federal Reserve's policies of forward guidance and quantitative easing on the entire term structure of interest rates over the interval when the federal funds rate itself was constrained by the zero lower bound. All data come from the Federal Reserve Bank of St. Louis' FRED database, except for the shadow funds rate series, 
which was downloaded from Jing Cynthia Wu's website at the Booth School of Business, University of Chicago.

Collecting the three data series in the $3 \times 1$ vector

$$
x_{t}=\left[\begin{array}{lll}
p_{t} & y_{t} & r_{t}
\end{array}\right]^{\prime}
$$

allows the structural VAR to be written compactly as

$$
A x_{t}=\mu+\sum_{j=1}^{q} B_{j} x_{t-j}+\varepsilon_{t} \text {, }
$$

where $A$ is a $3 \times 3$ matrix of impact coefficients with ones along the diagonal, $\mu$ is a $3 \times 1$ vector of intercept terms, each $B_{j}, j=1,2, \ldots, q$, is a $3 \times 3$ matrix of autoregressive coefficients, and $\varepsilon_{t}$ is a $3 \times 1$ vector of structural disturbances, assumed to be normally distributed with zero mean and diagonal 3x3 covariance matrix $D$. While (1) leaves the autoregressive dynamics unconstrained, the matrix of impact coefficients is constrained to give each equation its structural interpretation.

More specifically, with

$$
A=\left[\begin{array}{ccc}
1 & -\alpha_{p y} & 0 \\
-\alpha_{y r} & 1 & \alpha_{y r} \\
-\alpha_{r p} & -\alpha_{r y} & 1
\end{array}\right]
$$

the first equation from (1) can be written as

$$
p_{t}=\alpha_{p y} y_{t}+\varepsilon_{t}^{a s}
$$

after suppressing for the sake of clarity the intercept and autoregressive terms that also appear in (1) in order to focus on the assumed contemporaneous relationships between the variables. Equation (3) takes the form of a Phillips Curve relationship which, as suggested above, departs from both traditional Keynesian and classical formulations but remains fully consistent with New Keynesian theory by treating neither inflation nor the output gap as predetermined and allowing instead for simultaneity between these two variables. Likewise, the second equation from (1), 


$$
y_{t}=-\alpha_{y r}\left(r_{t}-p_{t}\right)+\varepsilon_{t}^{a d}
$$

captures the essence of the New Keynesian aggregate demand relationship, linking the output gap to monetary policy-induced movements in the real short-term interest rate. The third equation,

$$
r_{t}=\alpha_{r p} p_{t}+\alpha_{r y} y_{t}+\varepsilon_{t}^{m p}
$$

takes the same form as the Taylor (1993) Rule and describes how the central bank adjusts the federal funds rate systematically in response to movements in inflation and the output gap. Under these interpretations, the structural disturbances in the vector

$$
\varepsilon_{t}=\left[\begin{array}{lll}
\varepsilon_{t}^{a s} & \varepsilon_{t}^{a d} & \varepsilon_{t}^{m p}
\end{array}\right]^{\prime}
$$

correspond to aggregate supply, aggregate demand, and monetary policy shocks.

The reduced form associated with the structural model (1) can be written as

$$
x_{t}=v+\sum_{j=1}^{q} \Phi_{j} x_{t-j}+\zeta_{t} \text {, }
$$

where $v=A^{-1} \mu, \Phi_{j}=A^{-1} B_{j}$ for $j=1,2, \ldots, q$, and $\zeta_{t}=A^{-1} \varepsilon_{t}$ is a $3 \times 1$ vector of reduced-form innovations that is normally distributed with zero mean and $3 \times 3$ covariance matrix $\Omega=A^{-1} D\left(A^{-1}\right)^{\prime}$. The reduced form (6) summarizes all of the information contained in the data, and the availability of only three distinct off-diagonal elements in the reduced-form covariance matrix $\Omega$ implies that the structural model (1) remains unidentified unless at least one more restriction is imposed on the four parameters entering into the matrix $A$ as shown in (2). As an alternative, Baumeister and Hamilton (2015a, 2015b) outline methods for combining Bayesian prior distributions for the model's structural parameters with information contained in the data, and therefore communicated through the likelihood function, to characterize the posterior distributions for the structural parameters. These methods, however, do not solve the fundamental identification problem: within the Bayesian framework, the same problem manifests itself in the continued influence of the prior distribution in shaping the posterior, even as the number of observations in the data sample approaches infinity. Nevertheless, this 
Bayesian approach provides a coherent way of assessing how the information that is available in the data can be used to optimally update one's priors about the values of the structural parameters.

Thus, the analysis here follows Baumeister and Hamilton (2015b) by using New Keynesian theory as a guide for calibrating prior distributions for the elements of $A$ and, after characterizing the posterior distributions of the same parameters, asking whether the data provide any reason for doubting the statistical adequacy of that theory. Specifically, each of the four coefficients in (2) is assigned a Student $t$ prior distribution with two degrees of freedom and scale parameter equal to 0.3. The location parameter determining each coefficient's prior mean is set equal to 0.5 for the Phillips Curve coefficient $\alpha_{p y}$, consistent with the choice made by Lubik and Schorfheide (2004), 1.0 for the aggregate demand coefficient $\alpha_{y r}$, as would be implied by a logarithmic utility function for the representative household in a New Keynesian model, and 1.5 and 0.5 for the monetary policy coefficients $\alpha_{r p}$ and $\alpha_{r y}$, as suggested by the original Taylor (1993) Rule. Departing from Baumeister and Hamilton (2015b), the prior distributions for the monetary policy coefficients are not truncated at zero; this choice reflects a willingness to consider the possibility that the posterior distributions assign non-negligible weight to negative values for one or more of the structural parameters, which then would be interpreted as evidence against the theory. Burmeister and Hamilton's (2015b) specification also differs from the one used here by allowing for separate coefficients on the nominal interest rate and inflation in the aggregate demand equation (4); the hard restriction that these parameters are equal in absolute value and opposite in sign is imposed here in order to emphasize the New Keynesian model's implication that the effects of monetary policy on output are transmitted through the effects of policy on the real interest rate. ${ }^{12}$

\footnotetext{
12 In fact, Baumeister and Hamilton (2015b) find a large posterior probability that the coefficient on inflation in their aggregate demand relationship has the unexpected sign, associating a rise in inflation, holding the nominal interest rate constant, with a decline in aggregate demand. As discussed in more detail below, this finding may reflect omitted variable bias if, all else equal, higher inflation translates into a lower level of real money balances, which then depresses aggregate demand in an expanded, classical version of the IS curve.
} 
Conditional on these Student $t$ priors for the elements of $A$, the analysis continues to follow Baumeister and Hamilton (2015a, 2015b) by forming priors first for the diagonal elements of the covariance matrix $D$ for the structural shocks and then for the coefficients in the intercept and autoregressive coefficients in (1) by factoring the overall prior as

$$
p\left(A, D, \mu, B_{1}, B_{2}, \ldots, B_{q}\right)=p(A) p(D \mid A) p\left(\mu, B_{1}, B_{2}, \ldots, B_{q} \mid A, D\right)
$$

Specifically, conditional on A, the reciprocals of the three diagonal elements $d_{i i}, i=1,2,3$, of $D$ are assigned independent Gamma prior distributions with parameters $\kappa_{i}$ and $\tau_{i}$ such that $\kappa_{i} / \tau_{i}$ represents its prior mean and $\kappa_{i} / \tau_{i}^{2}$ its prior variance. Setting $\kappa_{i}=2$ for $i=1,2,3$ can be interpreted as placing a weight in these priors equal to that provided by $2 \kappa_{i}=4$

observations of data. The settings for each $\tau_{i}, i=1,2,3$, are then obtained by fitting univariate fourth-order autoregressions to each of the three series, computing the covariance matrix

$$
S=T^{-1} \sum_{t=1}^{T} e_{t} e_{t}^{\prime}
$$

where $e_{t}$ denotes the $3 \times 1$ vector of residuals from these univariate models, and assigning to $\tau_{i}$ a value equal to $\kappa_{i}$ times the corresponding diagonal element of $A S A^{\prime}$ when each element of $A$ is evaluated based on its own prior mean.

Finally, conditional on both $A$ and $D$, normal priors for the autoregressive parameters in the matrices $B_{j}, j=1,2, \ldots, q$, are calibrated based on Sims and Zha's (1998) modification of Litterman's (1986) "Minnesota" prior. With reference to the parameters of the structural model (1), this involves setting the prior mean of each element of the matrix $B_{1}$ equal to the prior mean of the corresponding element of $A$ and the prior mean of each element of the matrices $B_{j}, j=2,3, \ldots, q$, equal to zero, so as to imply random walk behavior in each variable according to the reduced form (6). The prior covariance for these autoregressive parameters is diagonal, with variance of the coefficient on lag $j=1,2, \ldots, q$ for variable $i=1,2,3$ given by 


$$
\frac{\lambda_{0}^{2} \lambda_{1}^{2}}{j^{2 \lambda_{2}} S_{i i}}
$$

where $s_{i i}$ denotes the ith diagonal element of the covariance matrix $S$ from (7), computed using the residuals from univariate fourth-order autoregressions fit to each of the series. The three elements of the intercept vector $\mu$ are assigned normal priors, each with mean zero and variance $\lambda_{0}^{2} \lambda_{3}^{2}$. Thus, as in Sims and Zha (1998), the hyperparameter $\lambda_{0}$ governs the overall weight on the Minnesota prior, $\lambda_{1}$ determines the weight on the prior belief that the reducedform (6) describes random-walk behavior for each variable, $\lambda_{2}$ controls how the tightness of the random-walk prior increases on autoregressive coefficients at longer lags, and $\lambda_{3}$ applies specifically to the tightness of the prior on the intercept terms. Following Baumeister and Hamilton $(2015 \mathrm{a}, 2015 \mathrm{~b})$, these hyperparameters are calibrated as $\lambda_{0}=0.2, \lambda_{1}=\lambda_{2}=1$, and $\lambda_{3}=100$ after setting $q=4$ so as to truncate the autoregressions after four lags in (1) and (6). Starting from these priors, the Metropolis-within-Gibbs sampling algorithm outlined by Baumeister and Hamilton (2015a, p.1989) is used to draw from the posterior, factored as

$$
p\left(A, D, \mu, B_{1}, B_{2}, B_{3}, B_{4} \mid X_{1: T}\right)=p\left(A \mid X_{1: T}\right) p\left(D \mid A, X_{1: T}\right) p\left(\mu, B_{1}, B_{2}, B_{3}, B_{4} \mid A, D, X_{1: T}\right),
$$

where $X_{1: T}$ denotes the sample of data on the three elements of $x_{t}, t=1,2, \ldots, T$. Draws for the reciprocals of the volatility parameters in $D$ and the intercept and autoregressive parameters in $\mu$ and $B_{j}, j=1,2,3,4$, are made directly from their conditional Gamma and Normal posterior distributions, whereas a random-walk Metropolis-Hastings step is required to generate draws from the posterior for the elements of $A .{ }^{13}$ After discarding the first one million draws to allow for burn in, the next one million draws are used to generate the results described next.

13 The tuning parameter $\xi=1$ for this Metropolis step is chosen here, again following Baumeister and Hamilton (2015a), to target a 30 percent acceptance rate. 
Table 1 summarizes the posterior distributions for the four coefficients in $A$ by reporting medians together with 16 and 84th percentiles; figure 1, meanwhile, compares in more detail the posterior density for each parameter, shown with blue bars, to the prior density, traced out with red lines. These results are tabulated and graphed when the model is estimated using the full sample of quarterly data running from 1967:1 through 2016:2 as well as when it is re-estimated with three disjoint subsamples of approximately equal length, corresponding to distinct episodes of United States economic and monetary history. ${ }^{14}$ The early subsample, running from 1967:1 through 1983:4, spans the period of the Great Inflation and "stop-go" monetary policy through the end of the Volcker disinflation. The middle subsample, from 1984:1 through 1999:4, corresponds to the Great Moderation. Finally, the recent subsample, from 2000:1 through 2016:2, covers the period running up to, including, and since the financial crisis and Great Recession of 2007-2009.

For the full sample and across all subsamples, the top rows of table 1 and figure 1 show the posterior distribution of the Phillips Curve parameter $\alpha_{p y}$ shifting noticeably to the left and tightening around a small median, relative to the prior. These smaller values for $\alpha_{p y}$ correspond to longer intervals between individual price adjustments in the Calvo (1983) model and, hence, additional price rigidity in the aggregate. Although the posterior median values of the parameter $\alpha_{y r}$ measuring the real interest elasticity of aggregate demand fall below the prior mean, the second row of figure 1 shows posterior densities from all sample periods that overlap considerably with the priors; this, of course, could reflect either a judicious choice of prior or a lack of information in the data that would lead to a revision in that prior. In general, posterior estimates of the response coefficient $\alpha_{r p}$ on inflation in the monetary policy rule decrease, while estimates of the response coefficient $\alpha_{r y}$ to the output gap increase, compared to the corresponding priors. The estimated strength of the policy response to inflation relative

${ }^{14}$ Baumeister and Hamilton (2015b), by contrast, focus exclusively on the period from 1986:1 through 2008:3. 
to output increases, however, moving from the early subsample before 1984 to the middle subsample that follows, consistent with the findings of Clarida, Gali, and Gertler (2000). The policy emphasis shifts strongly back towards output gap stabilization in the recent subsample, confirming the view that the Federal Reserve has been unusually aggressive in its efforts to promote the recovery from each of the past two recessions in 2001 and 2007-2009.15

Figures 2 through 4 combine information in the impact coefficients $A$ with information in the shock volatilities $D$ and the autoregressive parameters in the matrices $B_{j}, j=1,2,3,4$, by plotting impulse responses to the aggregate supply, aggregate demand, and monetary policy shocks that appear in (3)-(5). Although the methods used here, which draw on prior information to help estimate the parameters of the aggregate supply, aggregate demand, and monetary policy equations directly, were proposed by Baumeister and Hamilton (2015a) as alternatives to those that constrain the model's implied impulse responses using "sign restrictions," the impulse response in the graphs generally display their expected patterns. In particular, aggregate supply disturbances tend to raise inflation and lower the output gap, while calling forth a monetary tightening in the form of higher nominal interest rates. Aggregate demand shocks lead to higher inflation, output gaps, and interest rates, while monetary policy shocks associate interest rate increases with reductions inflation and output. Only the small increase in the output gap that accompanies higher inflation following an aggregate supply shock in the first and fourth columns of figure 2 and the higher inflation that follows a contractionary monetary policy shock in the fourth column of figure 4 appear as puzzles. But since these unexpected responses appear only when the model is estimated using data from the post-2000 period, they may simply reflect the fact that the small-scale, linear model in (1) fails to account fully for the dynamics associated with the Great Recession and its aftermath.

15 Belongia and Ireland (2016d) characterize and discuss this recent shift towards output stabilization in more detail, using a three-variable Bayesian VAR that allows the parameters of the identified policy rule to drift continuously over time. 
In general, therefore, this three-variable model appears successful in capturing well the New Keynesian view of the business cycle, with parameter estimates and impulse responses that have the expected magnitudes and signs. Like the New Keynesian model itself, however, this three-variable model omits any consideration of the role that changes in nominal and real money growth may play in shaping how monetary policy affects the economy. The results so far still leave open the possibility that interactions between money supply and demand, unseen by the New Keynesian model with its deliberate exclusion of them, may also be at work in the United States economy. The analysis now continues in order to explore this possibility.

\section{A Classical Alternative}

To detect evidence that classical channels of monetary transmission operate alongside, or perhaps even instead of, the New Keynesian mechanisms highlighted above, the set of variables included in the VAR is enlarged to include two more: the growth rate $m_{t}$ of the Divisia M2 monetary aggregate and the associated monetary user cost index $u_{t}$. Use of a Divisia monetary aggregate, in place of one of the Federal Reserve's official simple-sum measures, offers two distinct sets of advantages. First, as emphasized by Barnett (1980, 2012), simplesum monetary aggregates mismeasure the true flow of monetary services generated in an economy where agents have the ability and willingness to substitute between various liquid assets paying interest at different rates. By contrast, Divisia monetary aggregates, constructed using economic aggregation theory similar to that used to compute more familiar quantity aggregates such as real GDP and industrial production, successfully internalize substitution effects and thereby track true service flows much more accurately under a wide range of conditions. Consistent with Barnett's $(1980,2012)$ theory, empirical studies, including Belongia (1996), Hendrickson (2014), and Belongia and Ireland (2015b, 2016c), find evidence of links between Divisia monetary aggregates and key macroeconomic variables including inflation and output that are noticeably stronger than those between corresponding simplesum measures and the same macroeconomic indicators. Second, as discussed by Belongia 
(2006) and Belongia and Ireland (2015b, 2016b, 2016c), the user-cost dual to Divisia monetary aggregates first derived by Barnett (1978) is a variable that is likely to influence money demand but not money supply. Therefore, data on this variable can be put to good use in distinguishing movements in money growth that reflect shocks to monetary policy from movements in money growth that have worked, instead, to accommodate shifts in money demand. ${ }^{16}$

Barnett, Liu, Mattson, and van den Noort (2013) describe in more detail the procedures behind the construction of the series for the Divisia M2 quantity and user-cost indices employed here, which are available through the Center for Financial Stability's website. With these series included, the data vector expands to become

$$
x_{t}=\left[\begin{array}{lllll}
p_{t} & y_{t} & r_{t} & m_{t} & u_{t}
\end{array}\right]^{\prime} .
$$

The descriptions of the structural VAR and its reduced form shown previously in (1) and (6) remain unchanged, after all vectors and matrices are enlarged to accommodate the presence of the two additional variables. The autoregressive dynamics in (1) remain unconstrained, but the matrix of impact coefficients is again restricted to give the model its structural interpretation:

$$
A=\left[\begin{array}{ccccc}
1 & -\alpha_{p y} & 0 & 0 & 0 \\
\alpha_{y m}-\alpha_{y r} & 1 & \alpha_{y r} & -\alpha_{y m} & 0 \\
-\alpha_{r p} & -\alpha_{y r} & 1 & -\alpha_{r m} & 0 \\
-1 & -\alpha_{m y} & 0 & 1 & \alpha_{m u} \\
\alpha_{u m} & 0 & -\alpha_{u r} & -\alpha_{u m} & 1
\end{array}\right]
$$

In this expanded system, the first equation implied by (1) and (8) retains the same form shown in (3), of a Phillips Curve relationship drawing a contemporaneous link between inflation and the output gap. The second equation, which represents an augmented version of the New Keynesian aggregate demand curve, can be written as

16 Belongia and Ireland (2006) show how the Divisia monetary user cost variable can be used, as well, to directly measure the inflation-tax effects that allow monetary policy shocks to be non-neutral even in versions of the real business cycle model, such as Cooley and Hansen's (1989), that introduce a role for money as a medium of exchange while continuing to assume that nominal goods prices and wages remain perfectly flexible. 


$$
y_{t}=-\alpha_{y r}\left(r_{t}-p_{t}\right)+\alpha_{y m}\left(m_{t}-p_{t}\right)+\varepsilon_{t}^{m d}
$$

again suppressing the intercept and autoregressive terms in (1) to focus exclusively on impact effects. As discussed in Meltzer (2001), Ireland (2004), and Nelson (2008), this augmented aggregate demand curve incorporates the classical view that changes in nominal money growth, which translate into changes in the growth rate of real money balances over the interval during which nominal prices are slow to adjust, play a direct role in transmitting monetary policy actions to the real economy.

Likewise, the third equation, written as

$$
r_{t}=\alpha_{r p} p_{t}+\alpha_{r y} y_{t}+\alpha_{r m} m_{t}+\varepsilon_{t}^{m p}
$$

has one interpretation as an expanded Taylor (1993) Rule that includes the contemporaneous rate of nominal money growth, as well as inflation and the output gap, on the short list of variables to which the Federal Reserve is assumed to respond in setting its target for the federal funds rate. ${ }^{17}$ Alternatively, by keeping the term involving money growth on the lefthand side to express the relationship as

$$
r_{t}-\alpha_{r m} m_{t}=\alpha_{r p} p_{t}+\alpha_{r y} y_{t}+\varepsilon_{t}^{m p}
$$

this monetary policy rule can be seen to take the same general form as those used by Sims (1986), Leeper and Roush (2003), Leeper and Zha (2003), Sims and Zha (2006), Keating, Kelly, Smith, and Valcarcel (2014), Belongia and Ireland (2015b, 2016b), and Arias, Caldara, and Rubio-Ramirez (2016) to identify, within structural vector autoregressions, monetary policy shocks based on the contemporaneous effects those policy disturbances are allowed to have on both the federal funds rate and the rate of money growth. According to this interpretation, (10) associates a contractionary monetary policy shock, that is, a positive realization of $\varepsilon_{t}^{m p}$, with some combination of higher short-term interest rates and slower money growth, depending on the value of $\alpha_{r m}$.

17 Ireland (2001) estimates an equation of this form within a dynamic, stochastic New Keynesian model. Qureshi (2016) estimates the relationship using single equation methods. 
The fourth and fifth equations implied by (1) and (8) are entirely new and help distinguish movements in money growth triggered by monetary policy shocks from those reflecting shifts in the demand for monetary services by the non-bank public and in the behavior of the private banks that create deposits that contribute to broad measures of the money supply. The fourth equation takes the form

$$
m_{t}-p_{t}=\alpha_{m y} y_{t}-\alpha_{m u} u_{t}+\varepsilon_{t}^{m d}
$$

of a money demand relationship linking the growth rate of real money balances to the output gap as a scale variable and the user cost as an opportunity cost variable. As noted by Belongia (2006), besides their ability to track accurately movements in the non-bank public's true demand for monetary services, Divisia monetary aggregates offer the additional advantage of having, in their corresponding price dual $u_{t}$, a theoretically-coherent measure of the user cost of real monetary services. More conventional money demand specifications estimated for simple-sum aggregates, by contrast, typically use a short-term nominal interest rate to measure the opportunity cost of money, despite the fact that nominal interest rates reflect more closely the price of bonds as money substitutes than the price of the liquidity services yielded by monetary assets themselves. Drawing on this logic, (10) and (11) work to disentangle shocks to money supply from those to money demand in two ways. The first imposes the Quantity Theory's assumption that "money supply" refers to changes in the nominal quantity of money and "money demand" to changes in the real quantity of money. The second draws a sharper distinction between the role of the nominal interest rate as a variable that belongs in the money supply but not the money demand curve and the user cost of money as a variable that enters into the money demand function but not the money supply equation.

Finally, the fifth equation implied by (1) and (8), which takes the form

$$
u_{t}=\alpha_{u r} r_{t}+\alpha_{u m}\left(m_{t}-p_{t}\right)+\varepsilon_{t}^{m s}
$$

summarizes the behavior of the "monetary system" through which profit-maximizing private banks create deposits that contribute to the broad money supply. Belongia and Ireland (2014) incorporate a monetary system of this kind into an expanded version of the New Keynesian 
model and show how, in competitive equilibrium, banks pass increases in the federal funds rate $r_{t}$ along to their customers through an increase in the user cost of money $u_{t}$; the slightly more flexible specification shown here in (12) also allows for a channel through which $u_{t}$ will rise, as well, in response to an increase in the volume of real money balances created. Thus, in the expanded model, the five structural disturbances

$$
\varepsilon_{t}=\left[\begin{array}{lllll}
\varepsilon_{t}^{a s} & \varepsilon_{t}^{a d} & \varepsilon_{t}^{m p} & \varepsilon_{t}^{m d} & \varepsilon_{t}^{m s}
\end{array}\right]^{\prime}
$$

include the shock $\varepsilon_{t}^{m d}$ to money demand as well as the shock $\varepsilon_{t}^{m s}$ to the monetary system that makes it more or less costly for banks to create deposits that, together with currency, provide monetary services to the non-bank public.

Student $t$ prior distributions for the Phillips Curve parameter $\alpha_{p y}$, the aggregate demand elasticity $\alpha_{y r}$, and the monetary policy response coefficients $\alpha_{r p}$ and $\alpha_{r y}$ are specified and calibrated exactly as before for the smaller New Keynesian model. Meanwhile, the new parameters that appear in the expanded aggregate demand relationship (9) and monetary policy rule (10) but not in their simpler New Keynesian counterparts (4) and (5), also are assigned Student $t$ priors with two degrees of freedom and scale parameters equal to 0.3. However, both $\alpha_{y m}$, measuring the direct impact of changes in real money balances on aggregate demand in (9) and $\alpha_{r m}$, measuring the importance of changes in nominal money growth within the monetary policy rule (10), are assumed to have zero prior mean. These prior distributions are thereby centered so as to remain in alignment with the New Keynesian view that changes in real and nominal money play no role in shaping the dynamics of inflation, the output gap, and the short-term interest rate. But, at the same time, their large spread and fat tails leave ample opportunity for the data to either sharpen that New Keynesian perspective or shift it in favor of a "more classical" alternative.

Implementing this Bayesian exercise also requires the specification and calibration of prior distributions for the entirely new parameters that enter into the money demand and 
monetary system relationships (11) and (12). Though once a very active topic of research surveyed, for example, by Laidler (1985), the problem of estimating money demand equations has received almost no attention from monetary economists lately. Moreover, within the small set of recent empirical studies of money demand that includes, for example, Ireland (2009) and Benati, Lucas, Nicolini, and Weber (2016), virtually all focus on the properties of simple-sum monetary aggregates; no previous estimates of the parameters of a demand curve for Divisia money taking the form of (11) are available to serve as the basis for an informative prior here. ${ }^{18}$ Consider, therefore, as a long-run variant of (11), the specification

$$
\ln \left(\frac{M_{t} / P_{t}}{Y_{t}}\right)=\beta_{0}-\beta_{1} u_{t}+e_{t}^{m d}
$$

where $M_{t}$ denotes the level of the Divisia M2 quantity index, $P_{t}$ the PCE price index, $Y_{t}$ real GDP, $u_{t}$ the Divisia M2 user cost, and a unitary long-run scale elasticity has been imposed following Ireland (2009) and Benati, Lucas, Nicolini, and Weber (2016). If one continues to adopt as a benchmark the New Keynesian view that the aggregate demand function and monetary policy rule exclude all measures of money (both nominal or real), the federal funds rate $r_{t}$ will be predetermined relative to the long-run money demand disturbance $e_{t}^{m d}$ in (13). From this perspective, therefore, $r_{t}$ will be correlated with $u_{t}$ but not with $e_{t}^{m d}$ : It can be used as a valid instrument with which to obtain a consistent estimate of the slope parameter $\beta_{1}$. Using quarterly data, 1967:1 through 2016:2, for this purpose yields a point estimate of $\beta_{1}=1.5$ with a very large standard error of $4.9 .{ }^{19}$

\footnotetext{
18 Serletis and Gogas (2014) estimate long-run money demand relationships for Divisia monetary aggregates, but use the three-month United States Treasury bill rate in place of the Divisia user cost that appears in (11) to measure the opportunity cost of money.

19 In this instrumental variables estimation, the Wu-Xia (2016) shadow rate again substitutes for the effective federal funds rate over the period from 2009:1 through 2015:4 when the latter was up against its zero lower bound.
} 
Based on these results, Student $t$ priors are assigned to the money demand coefficients $\alpha_{m y}$ and $\alpha_{m u}$ in (11) with means equal to 1 and 1.5. For the additional parameters in the monetary system equation (12), about which even less is known, a prior mean of 5 for $\alpha_{u r}$ is set based on the simple observation that, in the raw data, fluctuations in the Divisia M2 user cost appear to be about five times as large as those in the federal funds rate. And a prior mean of 0 for $\alpha_{u m}$ is consistent with the simpler specification implied by the theoretical model in Belongia and Ireland (2014). All the Student $t$ priors for these four extra parameters have 2 degrees of freedom, but are assigned scale parameters equal to 10 to account for the larger amount of uncertainty that surrounds their values. Conditional on these priors for the elements of $A$, those for the elements of $D, \mu$, and $B_{j}, j=1,2,3,4$, are set and calibrated exactly as before, for the smaller-scale New Keynesian model. The same procedure is used to generate draws from the posterior, except that a setting of $\xi=0.6$ for the tuning parameter is now required to target an acceptance rate of 30 percent for the Metropolis step used to generate draws for the elements of $A$.

Thus, this empirical exercise is designed to mimic the thought pattern of an observer of the United States economy who, while satisfied with the description that the benchmark New Keynesian model provides, stands willing to be persuaded by the data that classical channels of monetary transmission are operative as well. The extent to which this persuasion occurs now hinges on the extent to which the posterior distributions shift in their locations away from the New Keynesian priors. And whatever dispersion may be left in the posterior distributions reflects uncertainty that remains, even after the data are analyzed carefully.

Table 2 and figures 5 and 6 help communicate the results of this thought experiment. Table 2 retains the format of table 1, summarizing posterior distributions for the ten elements of the expanded matrix $A$ from (8) by reporting medians together with 16 and 84th percentiles first for the full sample period from 1967:1 through 2016:2 and then for the three subsamples: early (1967:1-1983:4), middle (1984:1-1999:4), and recent (2000:1-2016:2). Figures 5 and 6 
provide more detailed information, comparing the posterior (blue bars) and prior (red lines) densities for the same coefficients.

Focusing first on the aggregate demand relationship, with the introduction of real balances into the expanded equation (9), the posterior distribution for the interest rate elasticity parameter shifts towards the left, placing additional weight on smaller values of $\alpha_{y r}$, while the posterior for the coefficient on real balances shifts to the right, favoring positive values of $\alpha_{y m}$. These results are strongest when the model is estimated over the full sample period and the early subsample; but even for the middle and recent subsamples, where the New Keynesian effects of changes in real interest rates are still evident through larger estimates of $\alpha_{y r}$, the estimates of $\alpha_{r m}$ appear quite sizable as well. These results serve, therefore, as a first indication that classical channels of monetary transmission working through changes in the money stock on aggregate demand are quantitatively important, despite their total absence from the New Keynesian model.

Baumeister and Hamilton (2015b) use data from 1986:1 through 2008:3 to estimate a three-variable VAR using New Keynesian priors, but allow for separate impact coefficients on the nominal interest rate and inflation in the aggregate demand relationship. Their posterior distributions tilt strongly towards values for these parameters that attribute declining output to increases in both the interest rate and inflation. While negative effects of the interest rate on aggregate demand are consistent with New Keynesian theory, the negative effect of inflation is more difficult to explain. Possibly, however, this finding provides evidence of the same type of misspecification uncovered here: with real balances omitted, their estimated aggregate demand curve may attribute to rising inflation effects that are due, instead, to more rapid growth in real balances. In any case, for both the middle and recent subsamples, which in combination cover the 1986-2008 period, the aggregate demand coefficients on the real interest rate and on real balances estimated here have their expected, positive, signs.

Table 2 and figure 5 show, as well, that the data prefer a more classical version of the monetary policy rule (10), in which money growth enters with a sizeable median coefficient of 
$\alpha_{r m}=1.2$ when estimated with the full sample of data. And while the median $\alpha_{r m}=0.56$ of the of the posterior distribution is smallest for the middle subsample, covering the period of the Great Moderation when Federal Reserve policy appeared to focus most closely on control of the federal funds rate, both the 84-16th percentile credibility interval shown in table 2 and the entire posterior density shown in figure 5 place heavy weight on distinctly positive values for this parameter; this result is consistent with previous findings by Ireland (2001) and Qureshi (2016) that point strongly towards a continued role for money in estimated Taylor Rules over the same period. Furthermore, from both table 2 and figure 5, the posterior distribution of $\alpha_{r m}$ for the most recent period from 2000:1 to 2016:2 appears quite similar to the posterior for the early subsample covering 1968:1 through 1983:4. There is, in particular, little if any evidence that the statistical importance of money in the policy rule has diminished in recent years relative to the more distant past. Once again, these results all point towards classical features of monetary policy and its effects on the economy that the smaller-scale New Keynesian model misses completely.

For the expanded model's remaining parameters, table 2 and, especially, figure 6 indicate that considerable uncertainty surrounds values for those appearing in both the money demand curve (11) and the monetary system equation (12). Posterior estimates of the scale elasticity of money demand $\alpha_{m y}$ drift higher than the value of unity imposed when estimating (13) via single-equation methods in order to calibrate the priors. The posterior distribution for the own-price elasticity $\alpha_{m u}$ parameter does tighten considerably, at least when viewed relative to the large standard error of the own-price elasticity estimated directly from (13); nevertheless, the prior mean value of 1.5 derived from the IV estimate from (13) is still covered by all of the posterior densities shown in the third row of figure 6. Finally, estimates of the coefficients of the monetary system equation (12) generally take their expected signs, associating a higher federal funds rate or a larger volume of real monetary services produced with higher values of the Divisia monetary user cost variable $u_{t}$. 
Figure 7 , meanwhile, reveals that the incorporation of monetary variables into the expanded VAR "fixes" the positive response in the output gap that follows an adverse supply shock shown in figure 2 for the smaller, New Keynesian specification. Here, across all sample periods, inflation rises and the output gap falls in response to the disturbance to aggregate supply. Likewise, in figure 8 , all impulse responses to aggregate demand shocks take their expected signs, with inflation, the output gap, and the nominal interest rate rising together after an expansionary disturbance. Real money balances, meanwhile, decline persistently following the shock, consistent with the sizable positive coefficients that appear on real balances in the estimated aggregate demand relationship (9).

Figure 9, however, provides the most striking evidence for the presence of distinctive, classical channels of monetary transmission not captured by contemporary macroeconomic models. In the top two rows, contractionary monetary policy shocks are followed consistently by persistent declines in both inflation and the output gap; the view provided by figure 9 is, therefore, quite different from that provided by a real business cycle, or purely "neoclassical," perspective. On the other hand, as shown vividly in the figure's third and fourth rows, a monetary tightening gets signaled by this model as a persistent deceleration in the rate of nominal money growth. The nominal interest rate displays, at most, a very small and purely transitory increase that is followed, quickly, by a more persistent decline. Although this fall in the nominal interest rate seems easy to explain, as a reflection of the declines in money growth and inflation that also follow this contractionary shock, it is far more difficult to reconcile with the New Keynesian view that associates lower nominal interest rates with a monetary policy easing instead.

To what extent do these results corroborate Irving Fisher's $(1923,1925)$ description of the "so-called business cycle" as a product of the "dance of the dollar?" Table 3 answers this question by decomposing the three-years-ahead forecast error variance in each of the model's five observable variables into percentages attributable to each of the five structural 
disturbances. ${ }^{20}$ According to the estimates, monetary policy shocks account for between 18 and 25 percent of the cyclical volatility of inflation and 13 and 31 percent of corresponding movements in the output gap. As expected, the Federal Reserve appears by these results to have been most successful at removing its own policies as a source of macroeconomic instability during the period of the Great Moderation from 1984:1 through 1999:4, though even for this subsample, the volatility associated with monetary policy shocks remains nontrivial. And from the perspective of the estimated model, the most recent episode from 2000:1 through 2016:1 appears as one of renewed monetary instability, with monetary policy disturbances accounting for a share of output gap volatility that is equal to or larger than those driven by shocks to aggregate supply and demand.

For the early subsample, especially, the results in table 3 attribute substantial amounts of inflation and output gap volatility to the money demand and monetary system shocks from (11) and (12). Impulse responses to these same shocks are plotted, for all sample periods, in figures 10 and 11 . In theory, money demand disturbances that are less than fully accommodated by a monetary policy response would be expected to decrease inflation and the output gap, while increasing the short-term nominal interest rate and the user cost of money. In figure 10, these effects on the interest rate and user cost variables appear right away, while the expected declines in inflation and output occur only with a lag. Moreover, while nominal money growth initially increases after the money demand shock, it declines later on. These somewhat puzzling effects, which also appear in Leeper and Roush (2003) and Belongia and Ireland (2015b), suggest that, after a long hiatus, efforts to better model the non-bank public's demand for monetary assets, if renewed, might yield valuable insights into the broader effects that monetary policy has had on the economy. Figure 11, meanwhile, shows that the monetary system shock that appears in (12) has macroeconomic effects resembling an additional aggregate demand disturbance, moving inflation, the output gap, and the short-term nominal interest rate in the same direction. Curiously, in all periods except that covered by the middle

20 The statistics reported in table 3 correspond to posterior mean values instead of posterior medians, so that the percentages across all shocks for each variable sum to 100 . 
subsample, this disturbance, which on impact should work to decrease the rate of broad money growth and increase the user cost of money, leads to a more persistent increase in money growth and decrease in the user cost. Again, these results point to the need for further research to better understand how the interactions between the Federal Reserve's policy choices and the behavior of the private banking system help shape the dynamics of the money supply process.

\section{Conclusion}

Though based on New Keynesian priors, the expanded VAR that is estimated here provides a posterior view of monetary policy and its effects on the economy that is highly "classical" instead. Within this estimated model, changes in real money balances play a key role, alongside movements in real interest rates, in transmitting the effects of monetary policy to real GDP over the period during which nominal rigidities prevent prices from adjusting fully. Likewise, changes in nominal money growth signal, much more clearly than changes in nominal interest rates, whether monetary policy is expansionary or contractionary. The estimated model attributes sizable fractions of the business cycle volatility in inflation and the output gap to monetary policy disturbances, particularly for the periods of macroeconomic instability before 1984 and since 2000 .

All of these results appear consistent with ideas expressed long ago by Fisher (1923, 1925, 1926) and Working $(1923,1926)$, that Quantity Theoretic interactions between money supply and money demand help shape the effects that Federal Reserve policy has on both inflation and output. None of these results, however, is easily reconciled with more recent theories of aggregate fluctuations. Real business cycle models, representing the latest stage in the evolution of "neoclassical" thought, cannot explain the interactions between nominal and real variables that appear to be as important today as they were in Fisher's time. New Keynesian models based on nominal price and wage rigidities do a better job than the earlier classical models of Lucas (1972), Sargent and Wallace (1975), and Sargent (1976) at capturing the short-run relationships between output and inflation first noted by Fisher (1926) and later 
incorporated into the Phillips Curve. ${ }^{21}$ On the other hand, the Bayesian priors that are updated here suggest strongly that, by focusing entirely on interest rates and excluding measures of money, the strict New Keynesian model provides an overly narrow view of channels through which monetary policy affects the economy.

These results call out for a new class of models, or at least substantial extensions of existing ones, that provide a richer and more realistic description of the monetary business cycle. They call out, as well, for a reconsideration of the role that monetary aggregates play in the formation of Federal Reserve policy. This line of research began to diminish after Friedman and Kuttner (1992) and Bernanke and Blinder (1992) published influential papers that suggested the funds rate, rather than the money supply, was the more powerful variable through which the effects of monetary policy were transmitted. However, replications of these studies by Belongia (1996) and Hendrickson (2014), using Divisia measures of money, reversed the earlier results and indicated money still had important effects on aggregate activity.

Research into the role that monetary aggregates might play in determining inflation and output has been impeded, however, by the Federal Reserve's reluctance to provide official measures of the money supply constructed according to the principles of monetary aggregation outlined by Barnett (1980). Indeed, there is more than a little irony in the fact that these same economic principles of aggregation are what the Fed uses to construct its official measures of industrial production. Moreover, the Fed has never adjusted its narrow simple-sum M1 aggregate for the distortionary effects of sweep accounts described by Cynamon, Dutkowsky, and Jones (2006), and, as discussed by Bernanke (2006), has not for years referred to either M1 or M2 as part of its regular policymaking procedures. The results presented here, however, support Barnett's (2012) claim that closer attention to, and improved measurement of, monetary data could help stabilize the United States economy, through the same channels identified, long ago, by Fisher and Working.

21 See Laidler $(1978,1990)$ and Taylor $(2016)$ for more on this point. 


\section{References}

Arias, Jonas E. Dario Caldara, and Juan F. Rubio-Ramirez. "The Systematic Component of Monetary Policy in SVARs: An Agnostic Identification Procedure." Manuscript. Atlanta: Emory University, August 2016.

Barnett, William A. "The User Cost of Money." Economics Letters 1 (Issue 2, 1978): 145149.

Barnett, William A. "Economic Monetary Aggregates: An Application of Index Number and Aggregation Theory.” Journal of Econometrics 14 (September 1980): 11-48.

Barnett, William A. Getting It Wrong: How Faulty Monetary Statistics Undermine the Fed, the Financial System, and the Economy. Cambridge: MIT Press, 2012.

Barnett, William A., Jia Liu, Ryan Mattson, and Jeff van den Noort. "The New CFS Divisia Monetary Aggregates: Design. Construction, and Data Sources." Open Economies Review 24 (February 2013): 101-124.

Baumeister, Christiane and James D. Hamilton. "Sign Restrictions, Strucutral Vector Autoregressions, and Useful Prior Information.” Econometrica 83 (September 2015a): 19631999.

Baumeister, Christiane and James D. Hamilton. “Optimal Inference about ImpulseResponse Functions and Historical Decompositions in Incompletely Identified Structural Vector Autoregressions.” Manuscript. San Diego: University of California, October 2015b.

Belongia, Michael T. "Measuring Matters: Recent Results in Monetary Economics Reexamined." Journal of Political Economy 104 (October 1996): 1065-1083.

Belongia, Michael T. “The Neglected Price Dual of Monetary Quantity Aggregates.” In Money, Measurement and Computation, Michael T. Belongia and Jane M. Binner. Eds. New York: Palgrave, 2006, pp.239-253.

Belongia, Michael T. and Peter N. Ireland. "The Own-Price of Money and the Channels of Monetary Transmission." Journal of Money, Credit, and Banking 38 (March 2006): 429-445. Belongia, Michael T. and Peter N. Ireland. "The Barnett Critique After Three Decades: A New Keynesian Analysis.” Journal of Econometrics 183 (November 2014): 5-21 
Belongia, Michael T. and Peter N. Ireland. "A 'Working' Solution to the Question of Nominal GDP Targeting.” Macroeconomic Dynamics 19 (April 2015a): 508-534.

Belongia, Michael T. and Peter N. Ireland. "Interest Rates and Money in the Measurement of Monetary Policy." Journal of Business and Economic Statistics 33 (April 2015b): 255-269.

Belongia, Michael T. and Peter N. Ireland. "Circumventing the Zero Lower Bound with Monetary Policy Rules Based on Money.” Working Paper 911. Chestnut Hill: Boston College, May 2016a.

Belongia, Michael T. and Peter N. Ireland. "Targeting Constant Money Growth at the Zero Lower Bound.” Working Paper 913. Chestnut Hill: Boston College, May 2016b.

Belongia, Michael T. and Peter N. Ireland. "Money and Output: Friedman and Schwartz Revisited.” Journal of Money, Credit, and Banking 48 (September 2016c): 1223-1266.

Belongia, Michael T. and Peter N. Ireland. "The Evolution of U.S. Monetary Policy: 2000

- 2007." Journal of Economic Dynamics and Control 73 (December 2016d): 78-93.

Benati, Luca, Robert E. Lucas, Jr. Juan Pablo Nicolini, and Warren Weber. “International Evidence on Long Run Money Demand.” Working Paper 22475. Cambridge: National Bureau of Economic Research, July 2016.

Bernanke, Ben S. and Alan S. Blinder. "The Federal Funds Rate and the Channels of Monetary Transmission.” American Economic Review 82 (September 1992): 901-921.

Bernanke, Ben S. "Monetary Aggregates and Monetary Policy at the Federal Reserve: A Historical Perspective." Speech given at the Fourth ECB Central Banking Conference. Frankfurt: 10 November 2006.

Calvo, Guillermo A. "Staggered Prices in a Utility-Maximizing Framework. Journal of Monetary Economics 12 (September 1983): 383-398.

Clarida, Richard, Jordi Gali, and Mark Gertler. "Monetary Policy Rules and Macroeconomic Stability: Evidence and Some Theory." Quarterly Journal of Economics 115 (February 2000): 147-180. 
Cooley, Thomas F. and Gary D. Hansen. "The Inflation Tax in a Real Business Cycle Model." American Economic Review 79 (September 1989): 733-748.

Cynamon, Barry Z., Donald H. Dutkowsky, and Barry E. Jones. "Redefining the Monetary Aggregates: A Clean Sweep.” Eastern Economic Journal 32 (Fall 2006): 1-12.

Fisher, Irving. The Purchasing Power of Money: Its Determination and Relation to Credit Interest and Crises. New York: The Macmillan Company, 1911.

Fisher, Irving. “The Equation of Exchange' for 1911, and Forecast.” American Economic Review 2 (June 1912): 302-319.

Fisher, Irving. “A Compensated Dollar.” Quarterly Journal of Economics 27 (February 1913): 213-235.

Fisher, Irving. Stabilizing the Dollar: A Plan To Stabilize the General Price Level Without Fixing Individual Prices. New York: The Macmillan Company, 1920.

Fisher, Irving. "The Business Cycle Largely a 'Dance of the Dollar." Journal of the American Statistical Association 18 (December 1923): 1024-1028.

Fisher, Irving. "Our Unstable Dollar and the So-Called Business Cycle." Journal of the American Statistical Association 20 (June 1925): 179-202.

Fisher, Irving. "A Statistical Relation between Unemployment and Price Changes." International Labour Review 13 (June 1926): 785-792.

Fisher, Irving. The Theory of Interest: As Determined by Impatience To Spend Income and Opportunity to Invest It. New York: The MacMillan Company, 1930.

Fisher, Irving. "Changes in the Wholesale Price Index in Relation To Factory Employment." Journal of the American Statistical Association 31 (September 1936): 496-502. Fisher, Irving. "I Discovered the Phillips Curve." Journal of Political Economy 81 (March/April 1973): 496-502.

Friedman, Benjamin M. and Kenneth N. Kuttner. "Money, Income, Prices, and Interest Rates.” American Economic Review 82 (June 1992): 472-492. 
Hallman, Jeffrey J., Richard D. Porter, and David H. Small. "Is the Price Level Tied to the M2 Monetary Aggregate in the Long Run?" American Economic Review 81 (September 1991): 841-858.

Hendrickson, Joshua R. "Redundancy or Mismeasurement? A Reappraisal of Money." Macroeconomic Dynamics 18 (October 2014): 1437-1465.

Humphrey, Thomas M. "Empirical Tests of the Quantity Theory of Money in the United States, 1900-1930." History of Political Economy 5 (Fall 1973): 285-316.

Humphrey, Thomas M. "The Choice of a Monetary Policy Framework: Lessons from the 1920s." Cato Journal 21 (Fall 2001): 285-313.

Ireland, Peter N. "Money's Role in the Monetary Business Cycle.” Working Paper 8815. Cambridge: National Bureau of Economic Research, February 2001.

Ireland, Peter N. “Money's Role in the Monetary Business Cycle.” Journal of Money, Credit, and Banking 36 (December 2004): 969-983.

Ireland, Peter N. "On the Welfare Cost of Inflation and the Recent Behavior of Money Demand." American Economic Review 99 (June 2009): 1040-1052.

Keating, John W., Logan J. Kelly, Andrew Lee Smith, and Victor J. Valcarcel. "A Model of Monetary Policy Shocks for Financial Crises and Normal Conditions.” Working Paper 14-11. Kansas City: Federal Reserve Bank of Kansas City, October 2014.

King, Robert G. and Mark W. Watson. "The Post-War U.S. Phillips Curve: A Revisionist Econometric History." Carnegie-Rochester Conference Series on Public Policy 41 (December 1994); 157-219.

Laidler, David. "Money and Money Income: An Essay on the 'Transmission Mechanism." Journal of Monetary Economics 4 (April 1978): 151-191.

Laidler, David. The Demand for Money: Theories, Evidence, and Problems 3rd Ed. New York: Harper and Row, 1985.

Laidler, David. "The Legacy of the Monetarist Controversy." Federal Reserve Bank of St. Louis Review 72 (March/April 1990): 49-64. 
Laidler, David. "Professor Fisher and the Quantity Theory: A Significant Encounter." European Journal of the History of Economic Thought 20 (April 2013): 174-205.

Leeper, Eric M. and Jennifer E. Roush. "Putting 'M' Back in Monetary Policy.” Journal of Money, Credit, and Banking 35 (December 2003): 1217-1256.

Leeper, Eric M. and Tao Zha. "Modest Policy Interventions.” Journal of Monetary Economics 50 (November 2003): 1673-1700.

Litterman, Robert B. "Forecasting With Bayesian Vector Autoregressions: Five Years of Experience." Journal of Business and Economic Statistics 4 (January 1986): 25-38.

Lubik, Thomas A. and Frank Schorfheide. "Testing for Indeterminacy: An Application to U.S. Monetary Policy.” American Economic Review 94 (March 2004): 190-217.

Lucas, Robert E., Jr. "Expectations and the Neutrality of Money." Journal of Economic Theory 4 (April 1972) 103-124.

Lucas. Robert E., Jr. "International Evidence on Output-Inflation Tradeoffs.” American Economic Review 63 (June 1973): 326-334.

Lucas, Robert E., Jr. "Nobel Lecture: Monetary Neutrality.” Journal of Political Economy 104 (August 1996): 661-682.

Meltzer, Allan H. “The Transmission Process.” In Deutsche Bundesbank, Ed. The Monetary Transmission Process: Recent Developments and Lessons for Europe. New York: Palgrave, 2001, pp.112-130.

Neiss, Katherine S. and Edward Nelson. "The Real-Interest-rate Gap as an Inflation Indicator." Macroeconomic Dynamics 7 (April 2003): 239-262.

Nelson, Edward. "Direct Effects of Base Money on Aggregate Demand: Theory and Evidence." Journal of Monetary Economics 49 (May 2002): 687-708.

Nelson, Edward. "Why Money Growth Determines Inflation in the Long Run: Answering the Woodford Critique." Journal of Money, Credit, and Banking 40 (December 2008): 17911814. 
Orphanides, Athanasios and Richard D. Porter. "P* Revisited: Money-Based Inflation Forecasts with a Changing Equilibrium Velocity." Journal of Economics and Business 52 (January-April 2000): 87-100.

Qureshi, Irfan. “The Role of Money in Federal Reserve Policy.” Manuscript. Coventry: University of Warwick, October 2016.

Sargent, Thomas J. "A Classical Macroeconometric Model for the United States." Journal of Political Economy 84 (April 1976): 207-238.

Sargent, Thomas J. and Neil Wallace. “'Rational' Expectations, the Optimal Monetary Instrument, and the Optimal Money Supply Rule." Journal of Political Economy 83 (April 1975): 241-254.

Serletis, Apostolos and Periklis Gogas. "Divisia Monetary Aggregates, the Great Ratios, and Classical Money Demand Functions.” Journal of Money, Credit, and Banking 46 (February 2014): 229-241.

Simons, Henry C. "Rules versus Authorities in Monetary Policy.” Journal of Political Economy 44 (February 1936): 1-30.

Sims, Chistopher A. “Are Forecasting Models Usable for Policy Analysis?” Federal Reserve Bank of Minneapolis Quarterly Review 10 (Winter 1986): 2-16.

Sims, Christopher A. and Tao Zha. "Bayesian Methods for Dynamic Multivariate Models." International Economic Review 39 (November 1998): 949-968.

Sims, Christopher A. and Tao Zha. "Were There Regime Switches in U.S. Monetary Policy?” American Economic Review 96 (March 2006): 54-81.

Taylor, John B. "Discretion Versus Policy Rules in Practice." Carnegie-Rochester Conference Series on Public Policy 39 (December 1993): 195-214.

Taylor, John B. "The Staying Power of Staggered Wage and Price Setting Models in Macroeconomics.” Manuscript. Stanford: Stanford University, March 2016.

Woodford, Michael. Interest and Prices: Foundations of a Theory of Monetary Policy. Princeton: Princeton University Press, 2003. 
Working, Holbrook. "Prices and the Quantity of Circulating Medium, 1890-1921." Quarterly Journal of Economics 37 (February 1923): 228-256.

Working, Holbrook. "Bank Deposits as a Forecaster of the General Wholesale Price Level.” Review of Economics and Statistics 8 (July 1926): 120-133.

Wu, Jing Cynthia and Fan Dora Xia. "Measuring the Macroeconomic Impact of Monetary Policy at the Zero Lower Bound." Journal of Money, Credit, and Banking 48 (March/April 2016): 253-291. 
Table 1. Impact Coefficients: New Keynesian Model

\begin{tabular}{|c|c|c|c|c|c|c|c|c|c|c|c|c|c|}
\hline & \multirow{4}{*}{$\begin{array}{l}\text { Prior } \\
\text { Mean }\end{array}$} & \multicolumn{12}{|c|}{ Posterior Percentiles } \\
\hline & & \multirow{2}{*}{\multicolumn{3}{|c|}{$\begin{array}{c}\text { Full Sample } \\
\text { 1967:1 - 2016:2 }\end{array}$}} & \multirow{2}{*}{\multicolumn{3}{|c|}{$\begin{array}{c}\text { Early Subsample } \\
1967: 1-1983: 4\end{array}$}} & \multirow{2}{*}{\multicolumn{3}{|c|}{$\begin{array}{c}\text { Middle Subsample } \\
\text { 1984:1 - 1999:4 }\end{array}$}} & \multirow{2}{*}{\multicolumn{3}{|c|}{$\begin{array}{c}\text { Recent Subsample } \\
\text { 2000:1 - 2016:2 }\end{array}$}} \\
\hline & & & & & & & & & & & & & \\
\hline & & 50 & 16 & 84 & 50 & 16 & 84 & 50 & 16 & 84 & 50 & 16 & 84 \\
\hline$\alpha_{p y}$ & 0.5 & 0.10 & 0.04 & 0.15 & 0.28 & 0.22 & 0.35 & 0.22 & 0.12 & 0.32 & 0.23 & 0.09 & 0.35 \\
\hline$\alpha_{\mathrm{yr}}$ & 1.0 & 0.76 & 0.60 & 0.92 & 1.01 & 0.83 & 1.22 & 0.93 & 0.76 & 1.12 & 0.78 & 0.63 & 0.94 \\
\hline$\alpha_{\mathrm{rp}}$ & 1.5 & 0.51 & 0.33 & 0.70 & 1.54 & 1.28 & 1.83 & 0.97 & 0.80 & 1.16 & 0.39 & 0.19 & 0.59 \\
\hline$\alpha_{\text {ry }}$ & 0.5 & 1.09 & 0.93 & 1.27 & 1.39 & 1.16 & 1.67 & 0.65 & 0.53 & 0.79 & 0.75 & 0.59 & 0.94 \\
\hline
\end{tabular}

Note: The Phillips curve coefficient $\alpha_{\mathrm{py}}$, the aggregate demand coefficient $\alpha_{\mathrm{yr}}$, and the monetary policy coefficients $\alpha_{\mathrm{rp}}$ and $\alpha_{\mathrm{ry}}$ each has a prior Student $t$ distribution with the indicated mean, scale parameter 0.3, and 2 degrees of freedom.

Table 2. Impact Coefficients: Classical Model

\begin{tabular}{|c|c|c|c|c|c|c|c|c|c|c|c|c|c|}
\hline & \multirow{3}{*}{$\begin{array}{l}\text { Prior } \\
\text { Mean }\end{array}$} & \multicolumn{12}{|c|}{ Posterior Percentiles } \\
\hline & & \multicolumn{3}{|c|}{$\begin{array}{c}\text { Full Sample } \\
\text { 1967:1 - 2016:2 }\end{array}$} & \multicolumn{3}{|c|}{$\begin{array}{c}\text { Early Subsample } \\
\text { 1967:1 - 1983:4 }\end{array}$} & \multicolumn{3}{|c|}{$\begin{array}{c}\text { Middle Subsample } \\
1984: 1-1999: 4\end{array}$} & \multicolumn{3}{|c|}{$\begin{array}{l}\text { Recent Subsample } \\
\text { 2000:1 - 2016:2 }\end{array}$} \\
\hline & & 50 & 16 & 84 & 50 & 16 & 84 & 50 & 16 & $\begin{array}{r}84 \\
84\end{array}$ & 50 & & 84 \\
\hline$\alpha_{p y}$ & 0.5 & 0.49 & 0.40 & 0.58 & 0.46 & 0.38 & 0.56 & 0.48 & 0.33 & 0.64 & 0.65 & 0.51 & 0.80 \\
\hline$\alpha_{y r}$ & 1.0 & 0.15 & -0.01 & 0.34 & -0.02 & -0.30 & 0.28 & 0.94 & 0.71 & 1.18 & 0.71 & 0.43 & 0.98 \\
\hline$\alpha_{y m}$ & 0.0 & 0.95 & 0.72 & 1.27 & 1.76 & 1.29 & 2.49 & 0.58 & 0.36 & 0.85 & 0.69 & 0.43 & 1.06 \\
\hline$\alpha_{\mathrm{rp}}$ & 1.5 & 1.93 & 1.61 & 2.41 & 1.86 & 1.52 & 2.40 & 1.63 & 1.43 & 1.89 & 1.35 & 1.05 & 1.61 \\
\hline$\alpha_{\text {ry }}$ & 0.5 & 1.66 & 1.38 & 2.00 & 1.61 & 1.31 & 1.98 & 0.78 & 0.61 & 0.99 & 1.20 & 0.89 & 1.61 \\
\hline$\alpha_{r m}$ & 0.0 & 1.20 & 0.94 & 1.53 & 0.79 & 0.53 & 1.10 & 0.56 & 0.39 & 0.79 & 0.76 & 0.54 & 1.05 \\
\hline$\alpha_{m y}$ & 1.0 & 1.12 & 0.44 & 1.82 & 1.25 & -0.37 & 2.96 & 2.52 & 1.63 & 3.53 & 2.38 & 0.64 & 4.43 \\
\hline$\alpha_{\mathrm{mu}}$ & 1.5 & 1.75 & 1.47 & 2.14 & 2.58 & 1.93 & 3.74 & 1.60 & 1.36 & 1.93 & 2.64 & 2.05 & 3.60 \\
\hline$\alpha_{u r}$ & 5.0 & 5.70 & 5.35 & 6.10 & 4.07 & 3.84 & 4.33 & 7.58 & 6.74 & 8.62 & 18.56 & 15.16 & 23.57 \\
\hline$\alpha_{\text {um }}$ & 0.0 & 0.46 & 0.19 & 0.76 & -0.14 & -0.41 & 0.15 & 1.13 & 0.79 & 1.54 & 2.47 & 1.48 & 3.80 \\
\hline
\end{tabular}

Notes: The Phillips curve coefficient $\alpha_{p y}$, the aggregate demand coefficients $\alpha_{y r}$ and $\alpha_{y m}$, and the monetary policy coefficients $\alpha_{r p}$, $\alpha_{r y}$, and $\alpha_{r m}$ each has a Student $t$ prior distribution with the indicated mean, scale parameter 0.3 , and 2 degrees of freedom. The money demand coefficients $\alpha_{m y}$ and $\alpha_{m u}$ and the monetary system coefficients $\alpha_{u r}$ and $\alpha_{u m}$ each has a Student $t$ prior distribution with the indicated mean, scale parameter 10 , and 2 degrees of freedom. 
Table 3. Three-Years-Ahead Forecast Error Variance Decompositions: Classical Model

\begin{tabular}{|c|c|c|c|c|c|c|c|c|c|c|}
\hline & \multicolumn{5}{|c|}{$\begin{array}{c}\text { Full Sample } \\
\text { 1967:1 - 2016:2 }\end{array}$} & \multicolumn{5}{|c|}{$\begin{array}{c}\text { Early Subsample } \\
\text { 1967:1 - 1983:1 }\end{array}$} \\
\hline & AS & $\mathrm{AD}$ & MP & MD & MS & AS & $\mathrm{AD}$ & MP & $\mathrm{MD}$ & MS \\
\hline $\mathrm{p}$ & 31 & 17 & 25 & 4 & 22 & 25 & 8 & 25 & 11 & 32 \\
\hline $\mathrm{y}$ & 41 & 17 & 30 & 6 & 6 & 19 & 9 & 21 & 24 & 27 \\
\hline $\mathrm{r}$ & 4 & 24 & 13 & 15 & 44 & 5 & 5 & 10 & 18 & 62 \\
\hline $\mathrm{m}$ & 4 & 54 & 20 & 12 & 11 & 7 & 17 & 10 & 14 & 51 \\
\hline \multirow[t]{3}{*}{$\mathrm{u}$} & 4 & 31 & 7 & 45 & 13 & 5 & 7 & 13 & 36 & 38 \\
\hline & \multicolumn{5}{|c|}{$\begin{array}{c}\text { Middle Subsample } \\
\text { 1984:1 - 1999:4 }\end{array}$} & \multicolumn{5}{|c|}{$\begin{array}{c}\text { Recent Subsample } \\
\text { 2000:1 - 2016:2 }\end{array}$} \\
\hline & AS & $\mathrm{AD}$ & MP & MD & MS & AS & $\mathrm{AD}$ & MP & MD & MS \\
\hline $\mathrm{p}$ & 38 & 33 & 18 & 6 & 4 & 32 & 30 & 20 & 4 & 14 \\
\hline $\mathrm{y}$ & 51 & 27 & 13 & 5 & 4 & 25 & 31 & 31 & 4 & 8 \\
\hline $\mathrm{r}$ & 16 & 47 & 9 & 16 & 11 & 11 & 32 & 8 & 8 & 41 \\
\hline $\mathrm{m}$ & 28 & 34 & 12 & 17 & 10 & 11 & 50 & 20 & 7 & 12 \\
\hline $\mathrm{u}$ & 20 & 30 & 7 & 38 & 4 & 8 & 33 & 6 & 32 & 21 \\
\hline
\end{tabular}

Note: Each entry reports the percentage of the variance of the three-years-ahead forecast error variance in inflation (p), the output gap $(\mathrm{y})$, the nominal interest rate $(\mathrm{r})$, Divisia money growth $(\mathrm{m})$, or the Divisia monetary user cost $(\mathrm{u})$ to aggregate supply (AS), aggregate demand (AD), monetary policy (MP), money demand (MD), or monetary system (MS) shocks. 
Figure 1. Prior and Posterior Densities of Impact Coefficients: New Keynesian Model
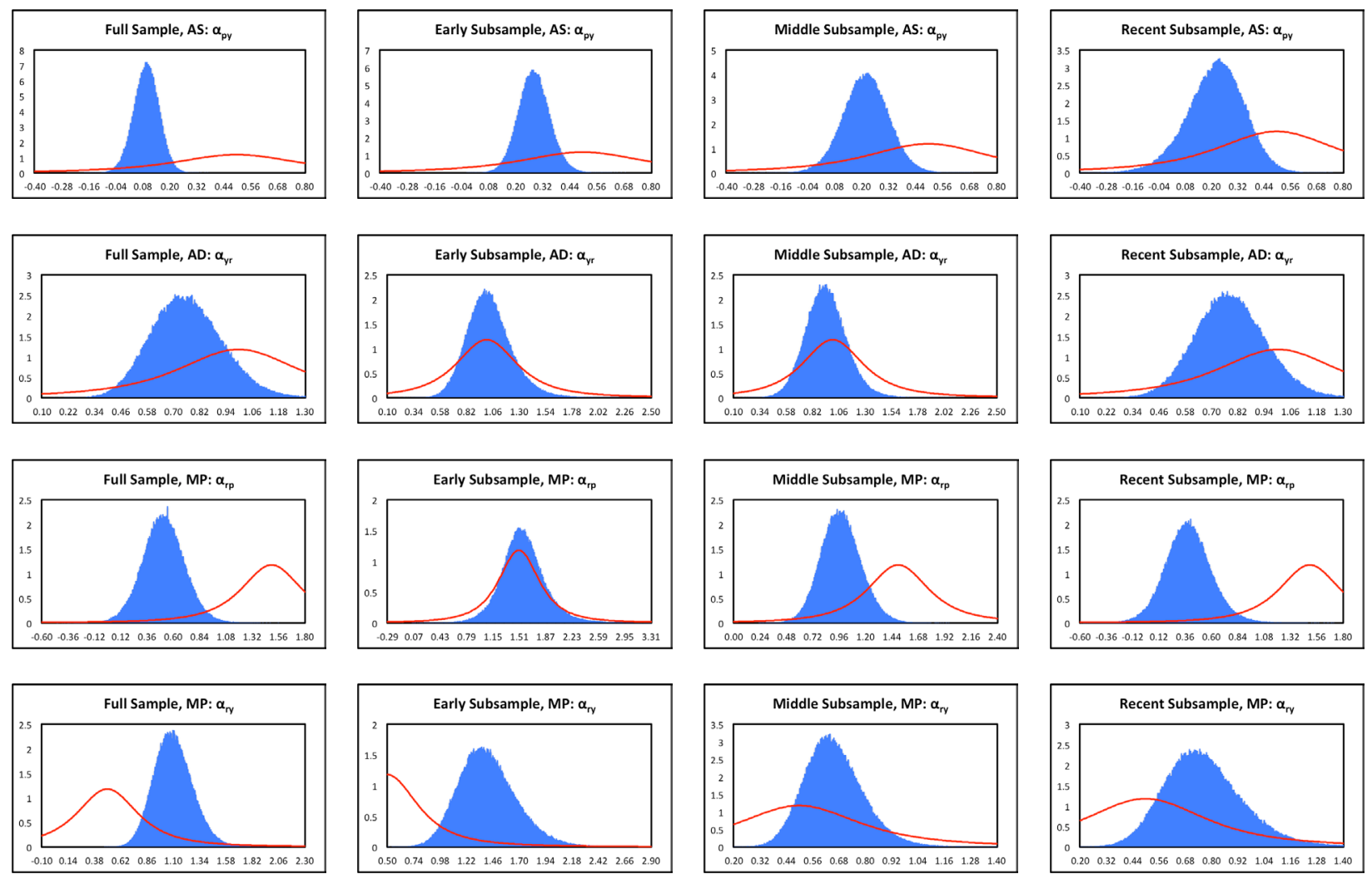

Note: Each panel illustrates the prior (red line) and posterior (blue bars) densities of the indicated parameter for the indicated sample period. 
Figure 2. Impulse Reponses: Aggregate Supply Shock, New Keynesian Model
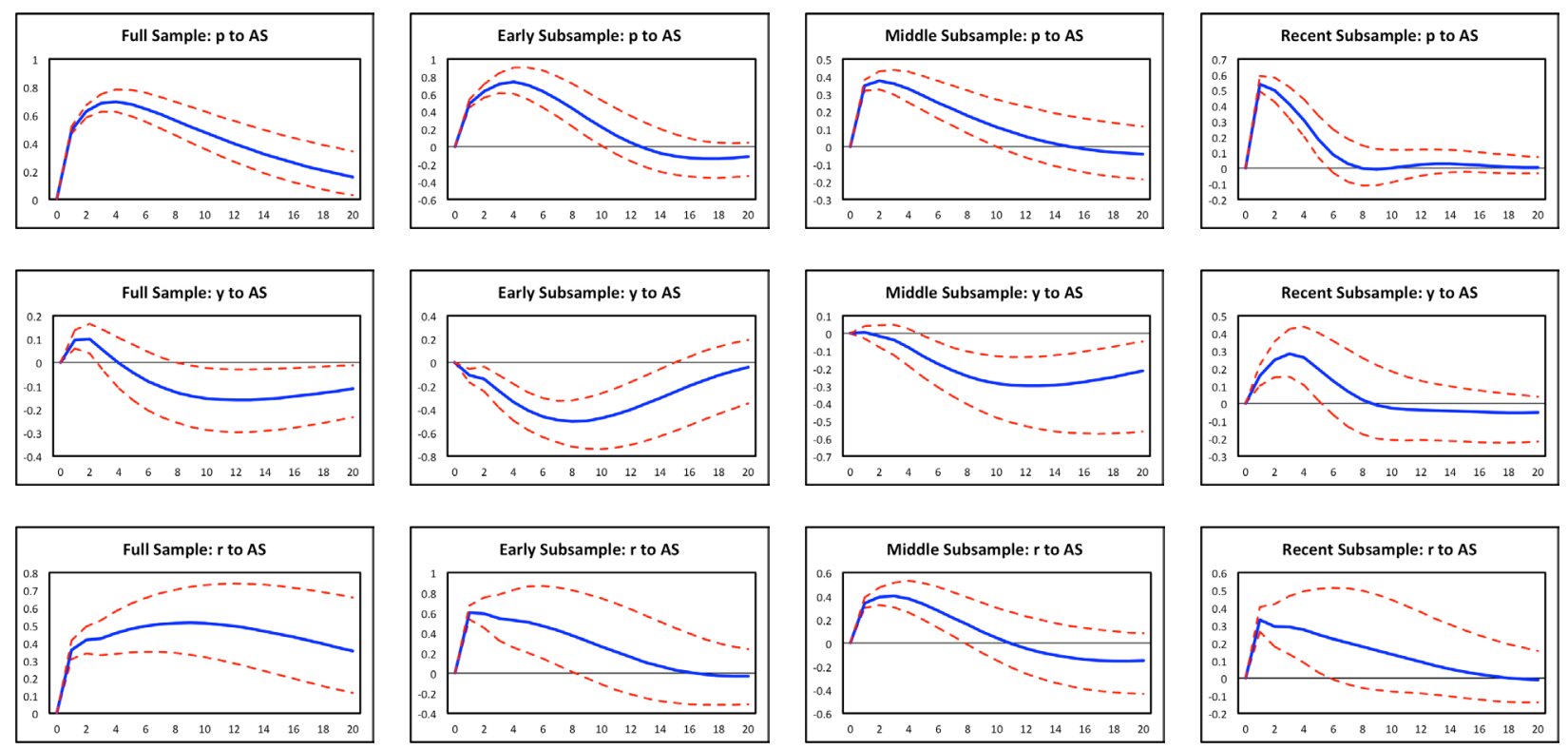

Note: Each panel shows the median (solid blue line) and 16th and 84th percentiles (dashed red lines) of the posterior distribution of the impulse response of inflation (p), the output gap (y), or the nominal interest rate $(r)$ to a one-standard-deviation aggregate supply shock during the indicated sample period. 
Figure 3. Impulse Reponses: Aggregate Demand Shock, New Keynesian Model
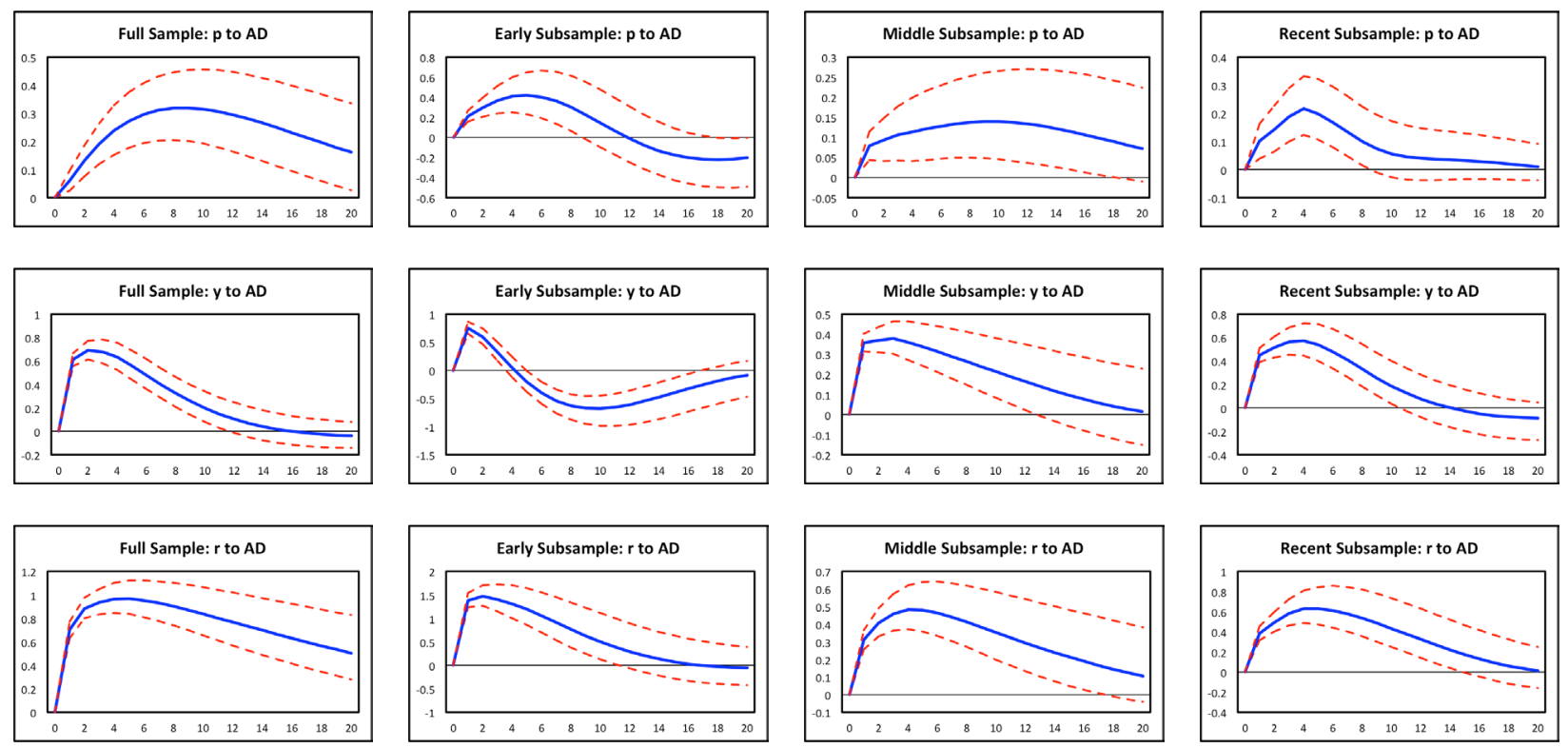

Note: Each panel shows the median (solid blue line) and 16th and 84th percentiles (dashed red lines) of the posterior distribution of the impulse response of inflation (p), the output gap (y), or the nominal interest rate $(r)$ to a one-standard-deviation aggregate demand shock during the indicated sample period. 
Figure 4. Impulse Reponses: Monetary Policy Shock, New Keynesian Model
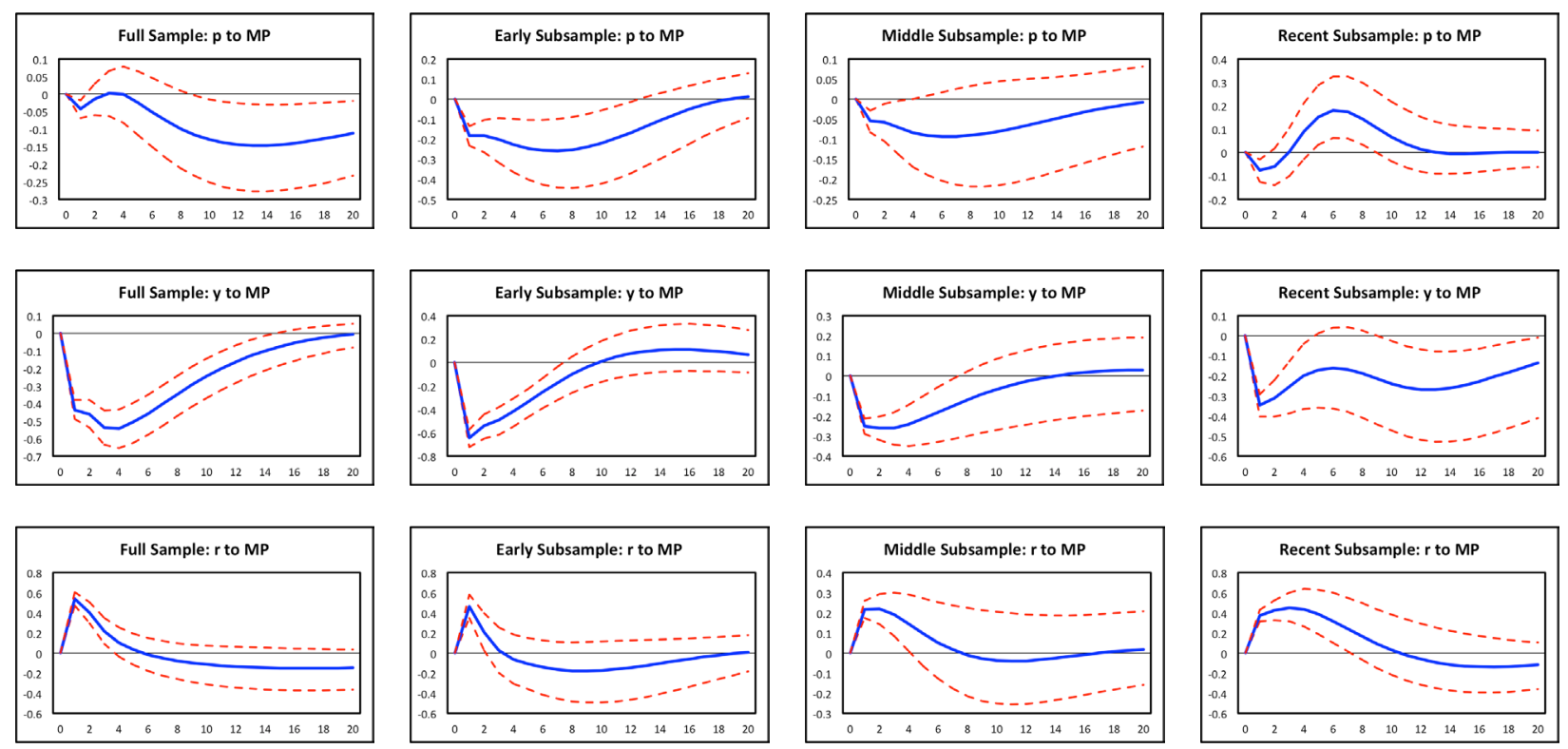

Note: Each panel shows the median (solid blue line) and 16th and 84th percentiles (dashed red lines) of the posterior distribution of the impulse response of inflation (p), the output gap (y), or the nominal interest rate (r) to a one-standard-deviation monetary policy shock during the indicated sample period. 
Figure 5. Prior and Posterior Densities of Impact Coefficients: Classical Model
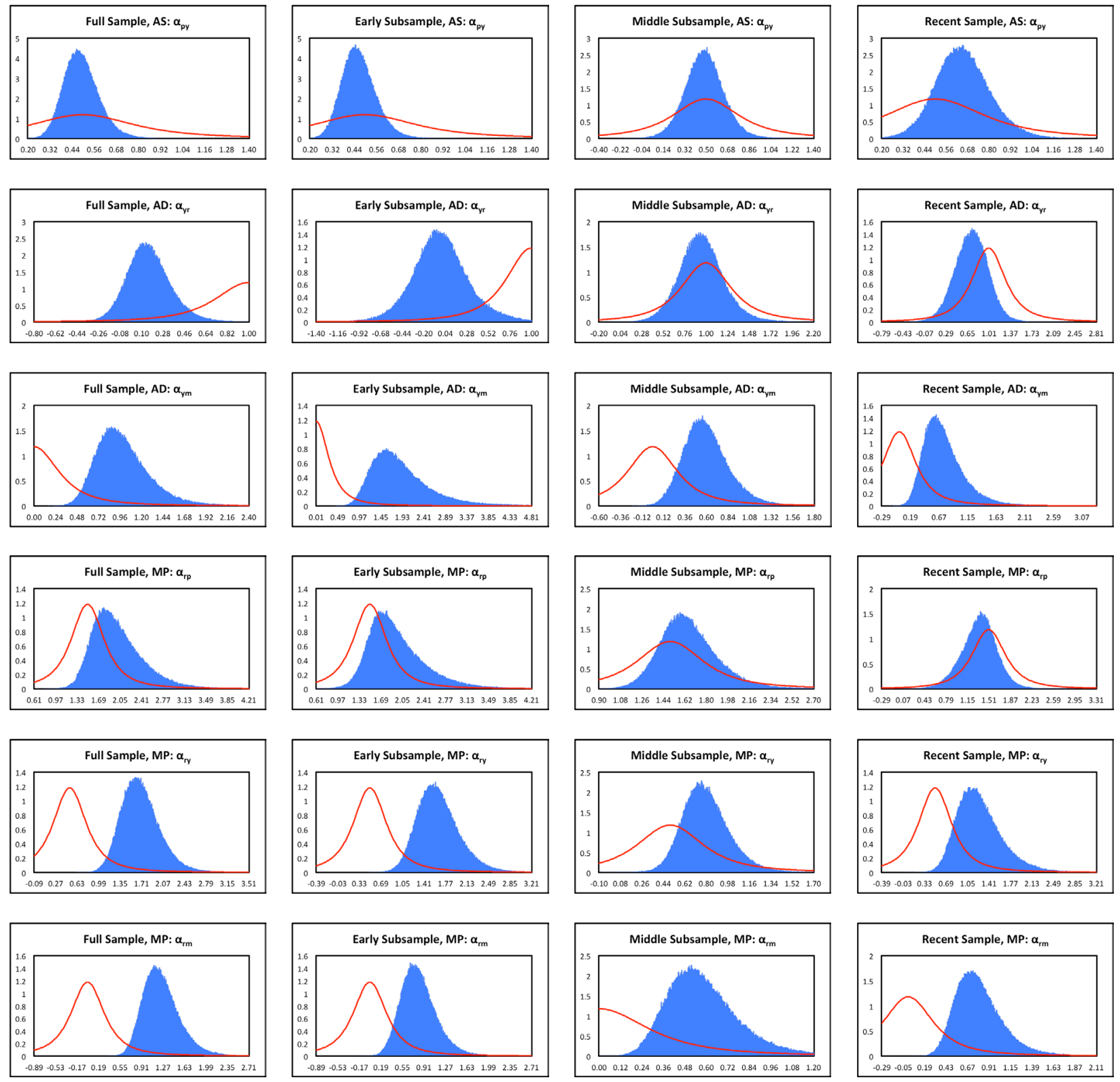

Note: Each panel illustrates the prior (red line) and posterior (blue bars) densities of the indicated parameter for the indicated sample period. 
Figure 6. Prior and Posterior Densities of Impact Coefficients: Classical Model
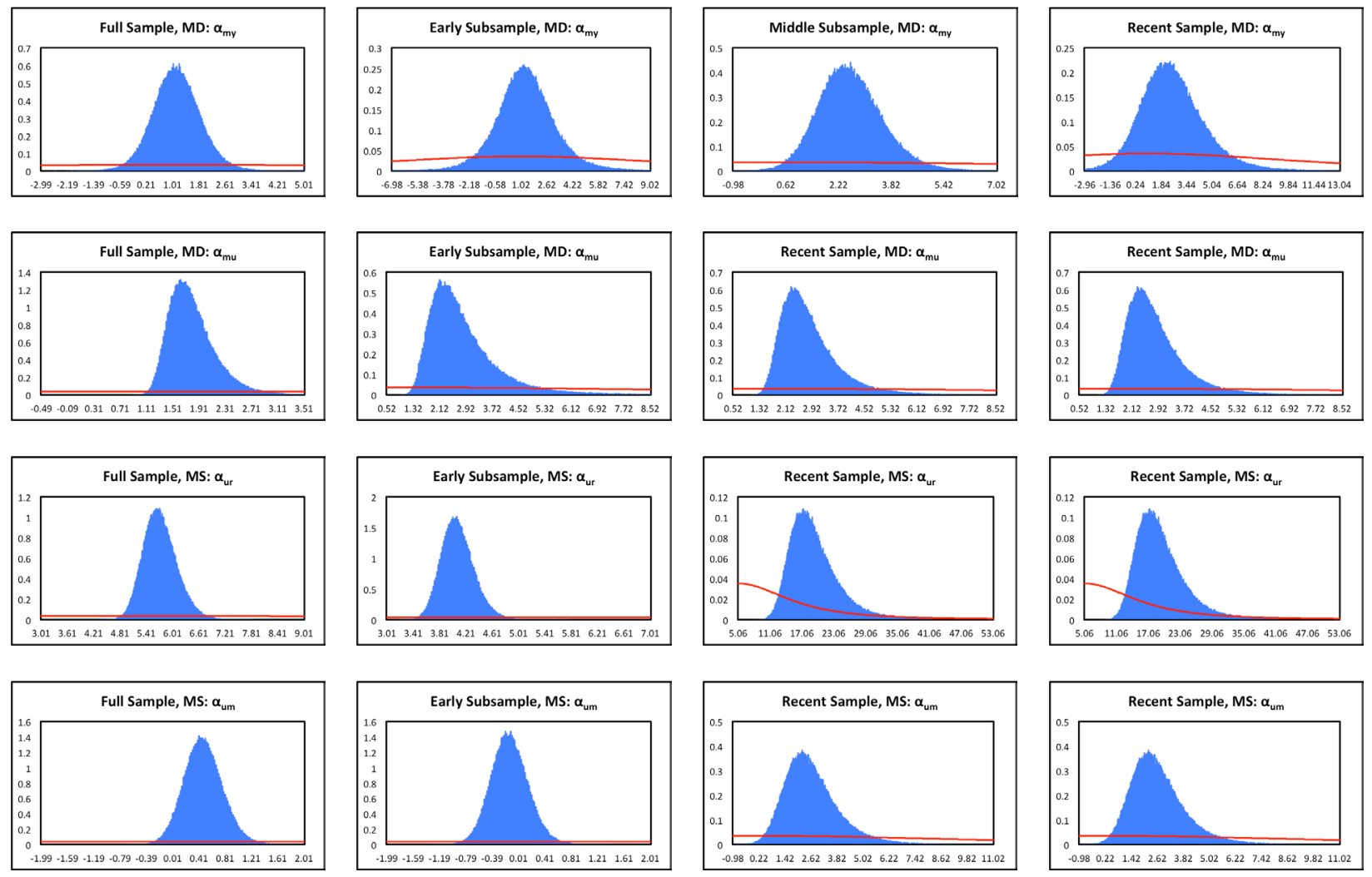

Note: Each panel illustrates the prior (red line) and posterior (blue bars) densities of the indicated parameter for the indicated sample period. 
Figure 7. Impulse Reponses: Aggregate Supply Shock, Classical Model
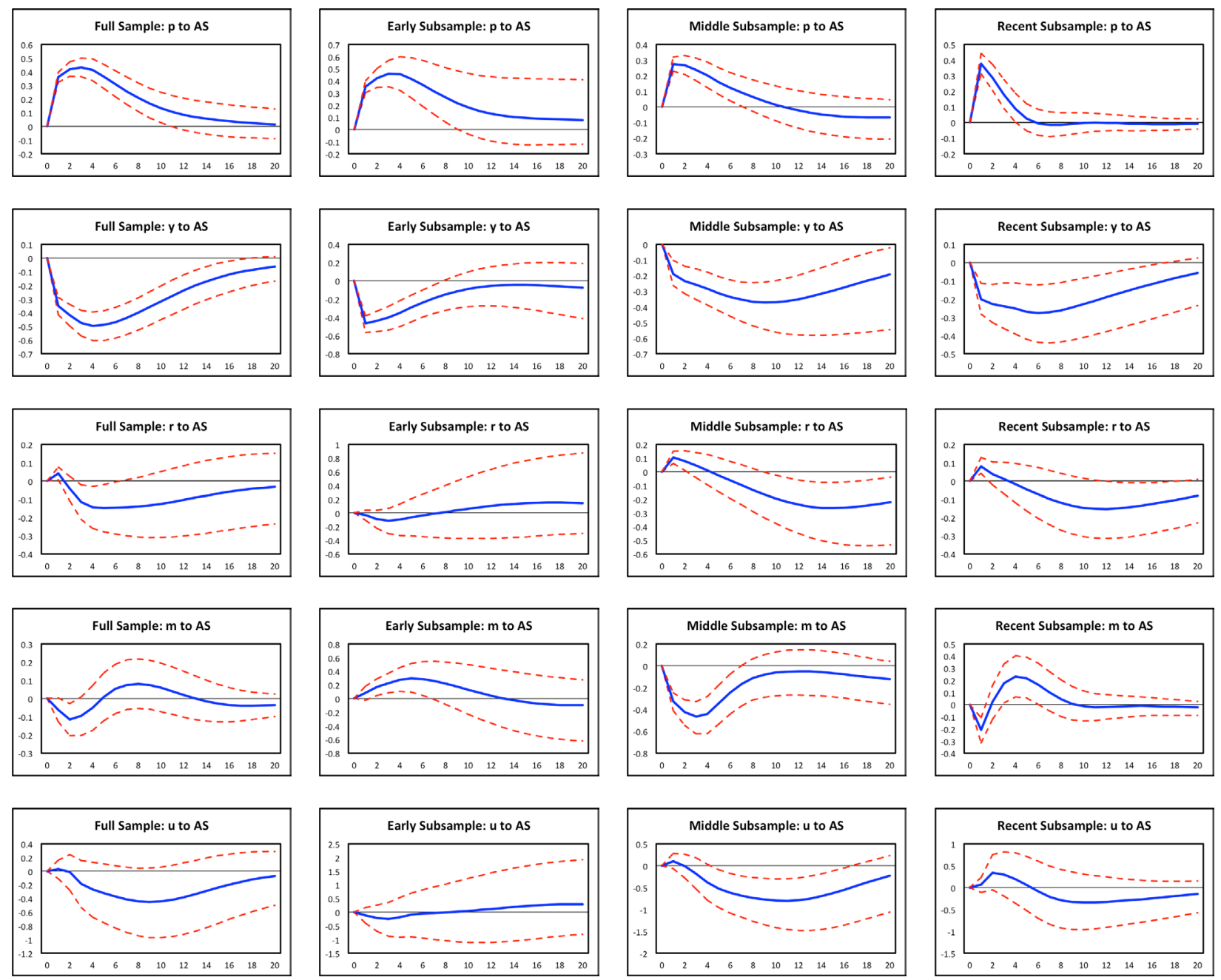

Note: Each panel shows the median (solid blue line) and 16th and 84th percentiles (dashed red lines) of the posterior distribution of the impulse response of inflation (p), the output gap (y), the nominal interest rate $(\mathrm{r})$, Divisia money growth $(\mathrm{m})$, or the Divisia monetary user cost $(\mathrm{u})$ to a one-standard-deviation aggregate supply shock during the indicated sample period. 
Figure 8. Impulse Reponses: Aggregate Demand Shock, Classical Model
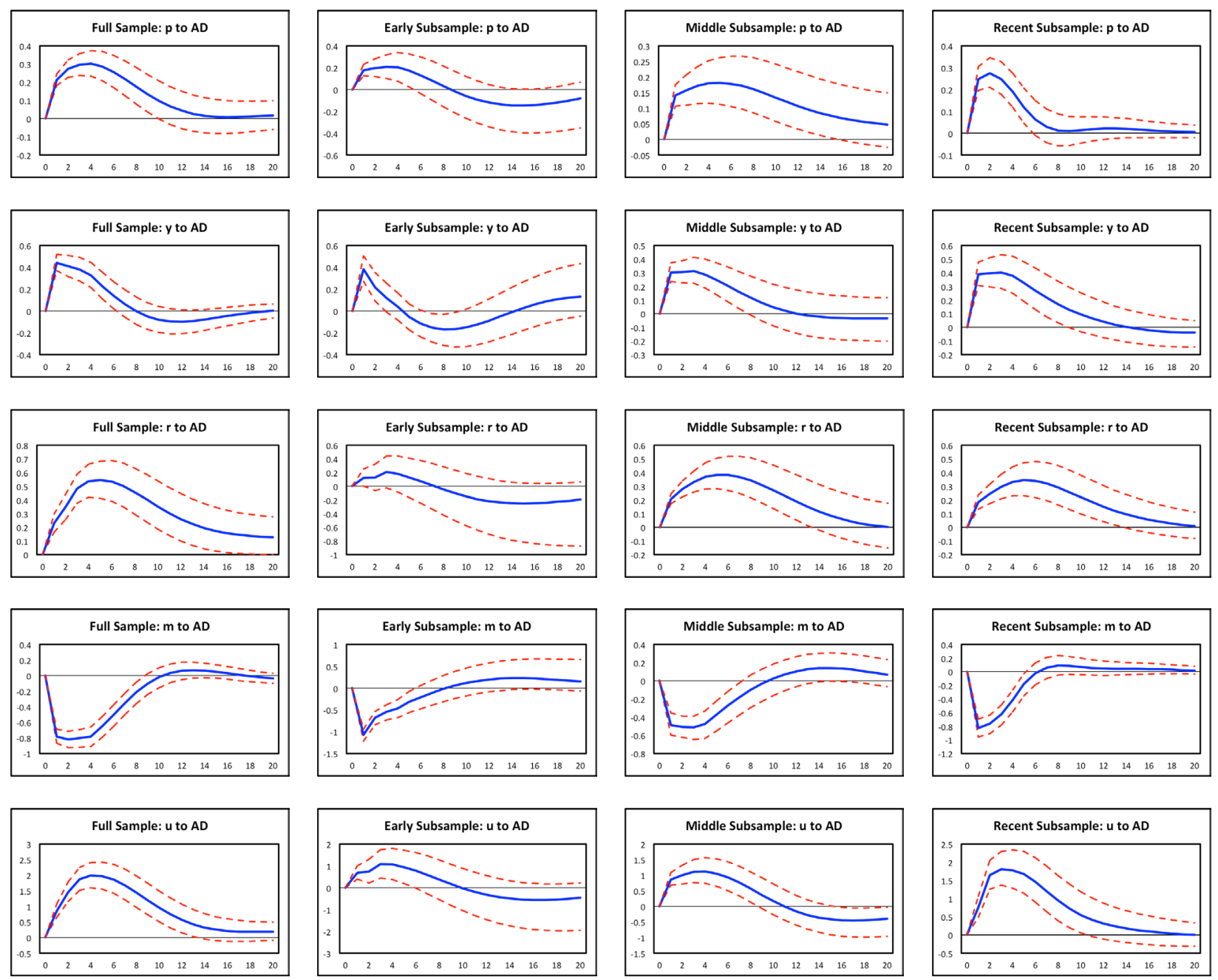

Note: Each panel shows the median (solid blue line) and 16th and 84th percentiles (dashed red lines) of the posterior distribution of the impulse response of inflation (p), the output gap (y), the nominal interest rate $(\mathrm{r})$, Divisia money growth $(\mathrm{m})$, or the Divisia monetary user cost $(\mathrm{u})$ to a one-standard-deviation aggregate demand shock during the indicated sample period. 
Figure 9. Impulse Reponses: Monetary Policy Shock, Classical Model
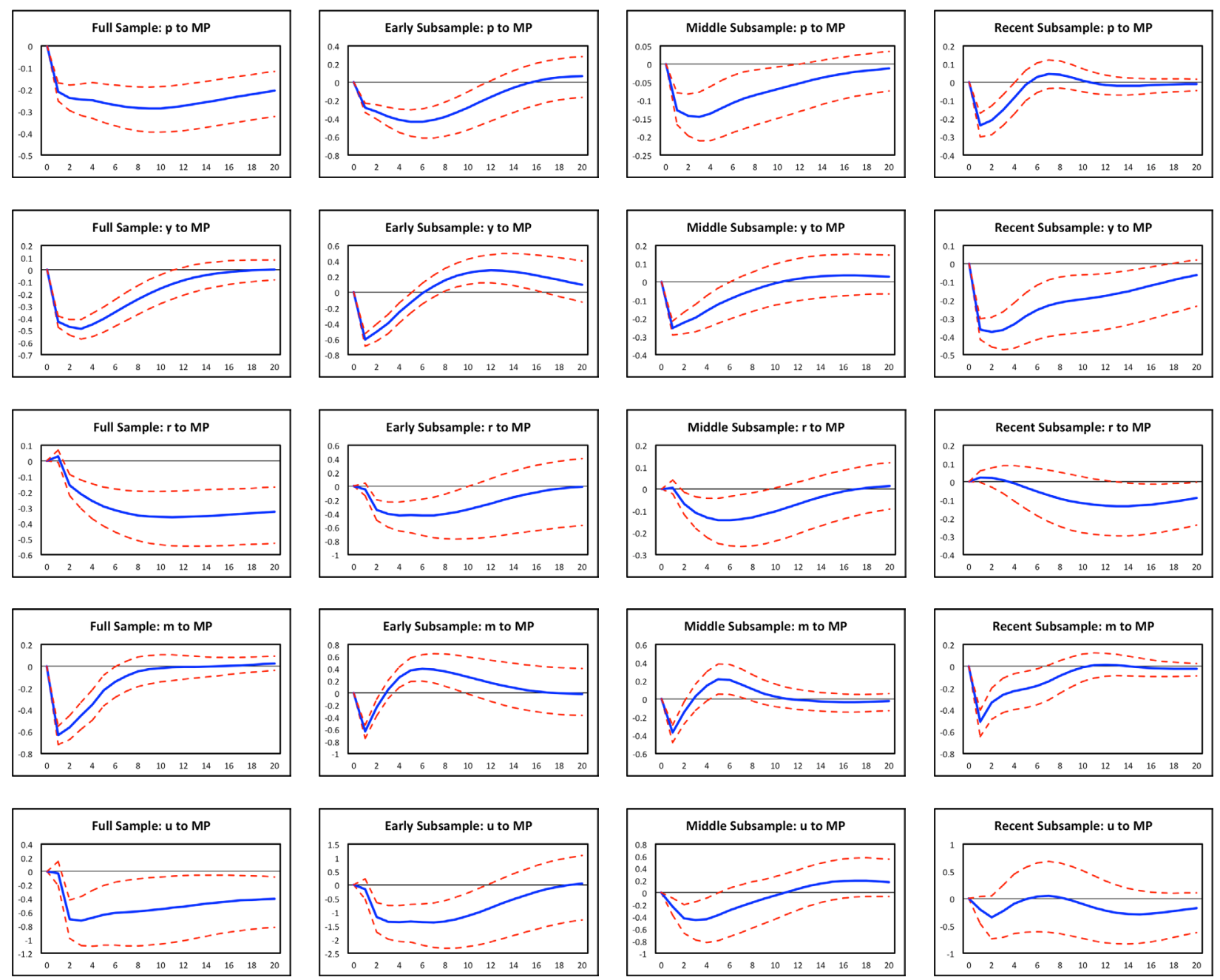

Note: Each panel shows the median (solid blue line) and 16th and 84th percentiles (dashed red lines) of the posterior distribution of the impulse response of inflation (p), the output gap (y), the nominal interest rate $(\mathrm{r})$, Divisia money growth $(\mathrm{m})$, or the Divisia monetary user cost $(\mathrm{u})$ to a one-standard-deviation monetary policy shock during the indicated sample period. 
Figure 10. Impulse Reponses: Money Demand Shock, Classical Model
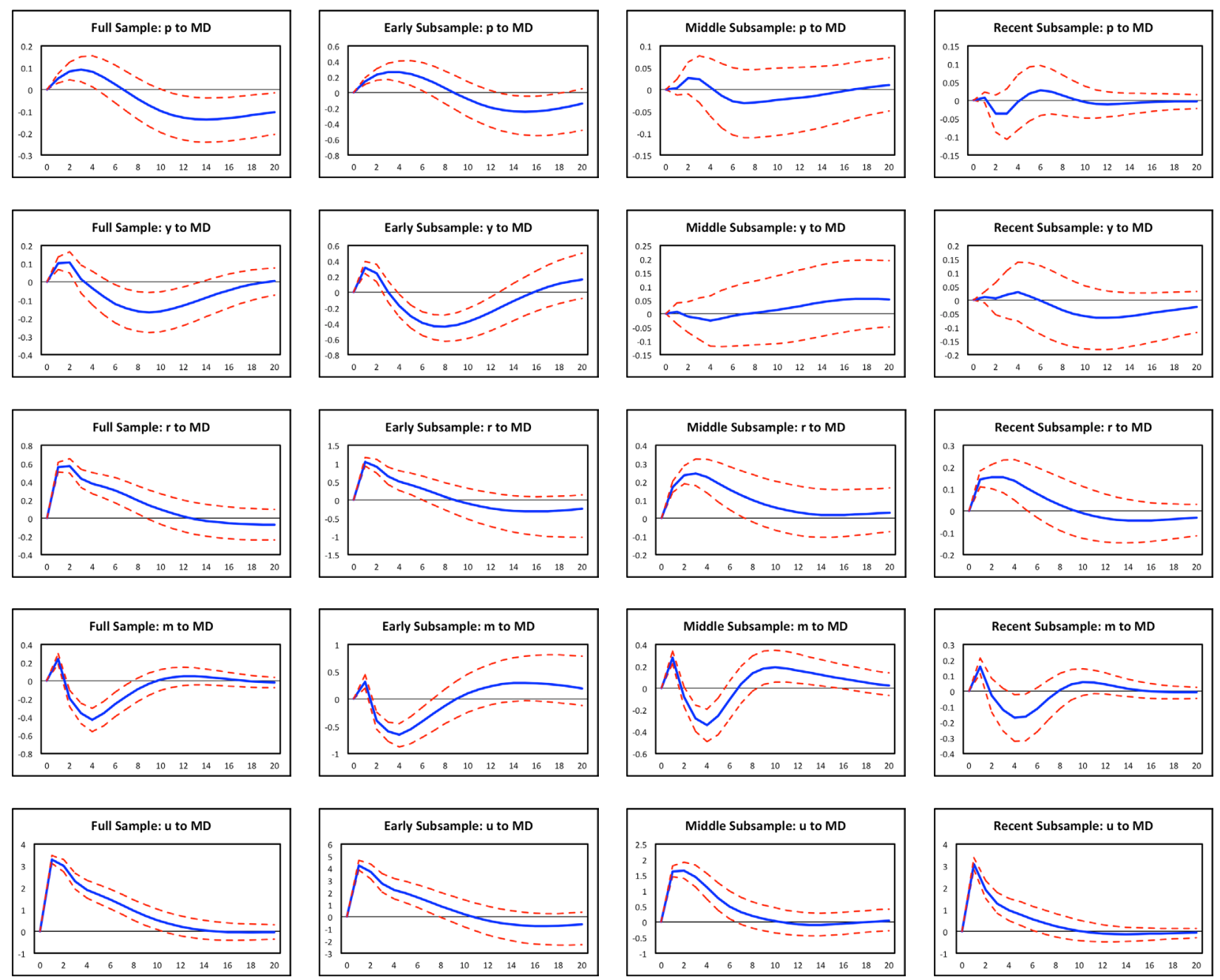

Note: Each panel shows the median (solid blue line) and 16th and 84th percentiles (dashed red lines) of the posterior distribution of the impulse response of inflation (p), the output gap (y), the nominal interest rate $(\mathrm{r})$, Divisia money growth $(\mathrm{m})$, or the Divisia monetary user cost $(\mathrm{u})$ to a one-standard-deviation money demand shock during the indicated sample period. 
Figure 11. Impulse Reponses: Monetary System Shock, Classical Model
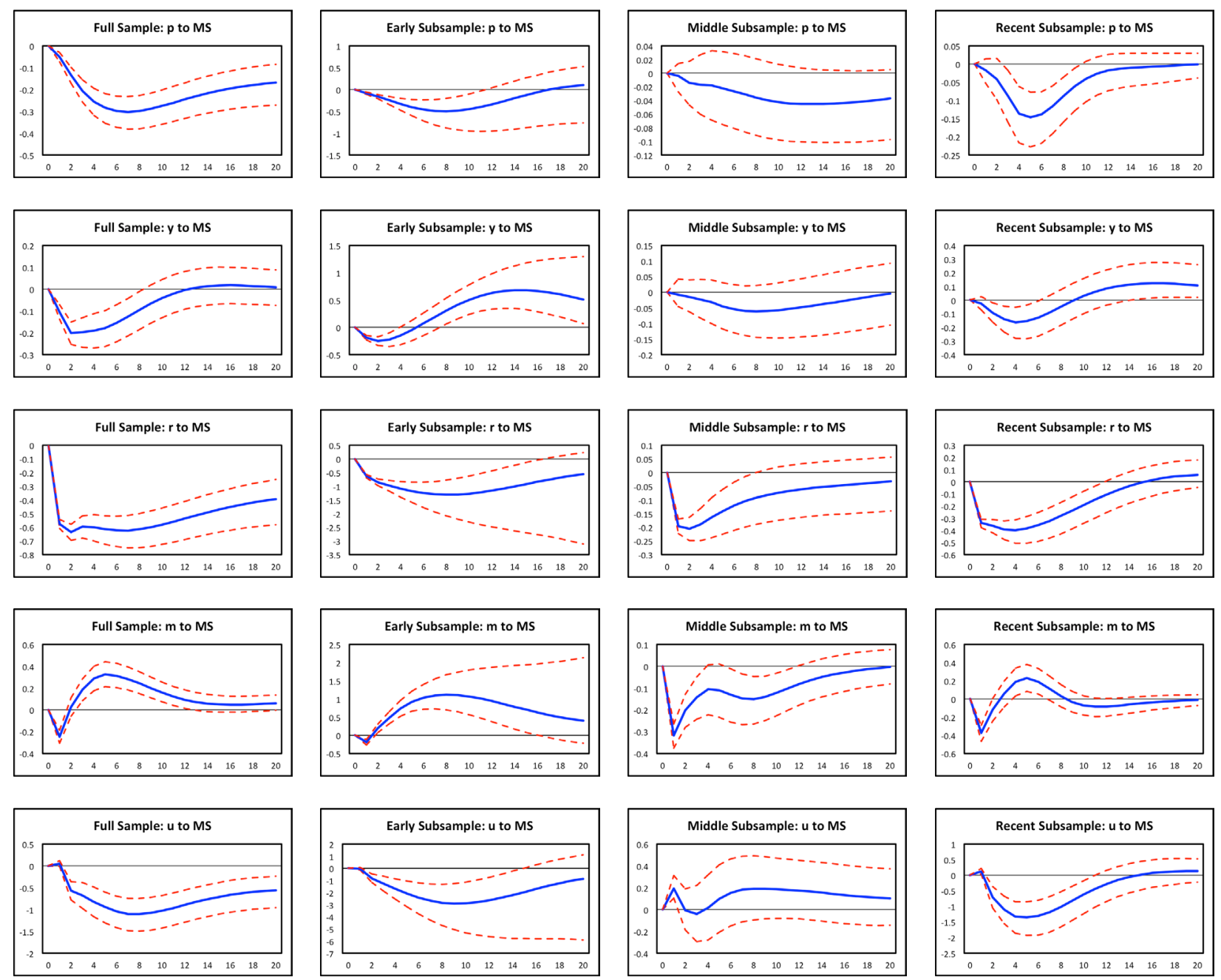

Note: Each panel shows the median (solid blue line) and 16th and 84th percentiles (dashed red lines) of the posterior distribution of the impulse response of inflation (p), the output gap (y), the nominal interest rate $(\mathrm{r})$, Divisia money growth $(\mathrm{m})$, or the Divisia monetary user cost $(\mathrm{u})$ to a one-standard-deviation monetary system shock during the indicated sample period. 